Rhode Island College

Digital Commons @ RIC

\title{
Comparison of Guekensia Demissa Populations Along a Nitrogen Loading Gradient in Narragansett Bay, RI
}

Janis Hall

Rhode Island College

Follow this and additional works at: https://digitalcommons.ric.edu/etd

Part of the Biology Commons, and the Marine Biology Commons

\section{Recommended Citation}

Hall, Janis, "Comparison of Guekensia Demissa Populations Along a Nitrogen Loading Gradient in Narragansett Bay, RI" (2013). Master's Theses, Dissertations, Graduate Research and Major Papers Overview. 101.

https://digitalcommons.ric.edu/etd/101

This Thesis is brought to you for free and open access by the Master's Theses, Dissertations, Graduate Research and Major Papers at Digital Commons @ RIC. It has been accepted for inclusion in Master's Theses, Dissertations, Graduate Research and Major Papers Overview by an authorized administrator of Digital Commons @ RIC. For more information, please contact digitalcommons@ric.edu. 
COMPARISON OF GEUKENSIA DEMISSA POPULATIONS ALONG A NITROGEN LOADING GRADIENT IN NARRAGANSETT BAY, RI

by Janis Hall

\begin{abstract}
A Thesis submitted in Partial Fulfillment
of the Requirements for the Master's Degree

in The Department of Biology

in The School of Arts and Sciences
\end{abstract}

Rhode Island College

2013 


\begin{abstract}
Anthropogenic eutrophication of coastal estuaries impacts these vital ecosystems by increasing primary production, hypoxic conditions, pathogen concentration, and greenhouse gas emissions, all of which are leading to the degradation of shorelines, disease transmission, and hypoxia-related fish kills. Narragansett Bay is a prominent feature of Rhode Island, making up over $500 \mathrm{~km}$ of coastline and acting as a watershed for over 2,000 square meters of land in both Massachusetts and Rhode Island. This estuary is important to both the economy of the state of Rhode Island and its fringing ecosystems are necessary for a healthy shoreline. The beaches of Narragansett Bay revenue over $\$ 5$ billion a year in tourism, stimulate more than 40,000 jobs, and are a source of many economically important marine organisms such as oysters, mussels, hard shell clams, finfish, and lobsters. The numerous fringing habitats of Narragansett Bay, including rocky intertidal zones, seagrasses, and estuarine marshes all play important roles for the coastline of Rhode Island, with salt marshes accounting for more than 600 ha of the shoreline.
\end{abstract}

Salt marshes along Narragansett Bay serve many ecological roles including water quality maintenance, storm surge reduction, erosion control, and habitat and food to fish and wildlife. The ribbed mussel, Geukensia demissa is the biomass-dominant benthic invertebrate in coastal marshes and is a foundation species, providing habitats for other organisms. Ribbed mussels have also been found to be a useful indicator species of nitrogen levels within Narragansett Bay, exhibiting increases in nitrogen-loads with greater biomass, density, and growth rates, and the $\delta^{15} \mathrm{~N}$ signatures of $G$. demissa tissues reflect anthropogenic-derived nitrogen. The purpose of my thesis was to compare ribbed mussel populations in some of the same salt marshes along the well-documented nitrogen-loading gradient, 14 years after the previous studies and following the installation of one phase of a two-part wastewater reduction program into the bay. In addition, 
my work is part of a larger effort to investigate changes in greenhouse gas emissions by plants, sediment microbiota, and gut microbiota in the ribbed mussels, in response nitrogen-loading and elevated temperatures. Characterizing the mussel populations is integral to understanding the effects of global change on the Narragansett Bay ecosystem.

The density, biomass, condition index, and growth rates of ribbed mussels were all positively correlated with the nitrogen-loading gradient in Narragansett Bay. Fecundity did not follow the same pattern but was significantly greater in June at one of the marshes and was negatively correlated with shell length and condition index. These results suggest that although mussels reproduce continuously, gametogenesis and spawning may have occurred prior to sampling. Another unexpected outcome is that with greater food availability resulting from nitrogen-loading, there are both costs and benefits. At the marsh with the highest nitrogen levels, Apponaug, the recruitment, growth, and condition index of the mussels were all significantly greater than at the other two marshes, but the high density may have limited the size of the mussels or even contributed to higher rates of mortality through intraspecific competition. At the opposite end of the nitrogen-loading gradient, mussels at Fox Hill had the greatest average shell length, but the density, biomass, condition index, recruitment, and growth rates were significantly lower than the other two marshes, suggesting that this less perturbed marsh may still be nitrogen-limited despite the historical nitrogen-loading in Narragansett Bay.

The results from this study are critical for documenting the variation among the ribbed mussel populations within differing nitrogen-loaded marshes, but will also be used as a benchmark for a longer-term study analyzing the historical responses of this species to changes in nutrient loads into Narragansett Bay. 


\section{TABLE OF CONTENTS}

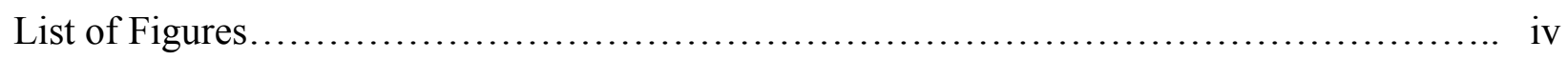

List of Tables............................................................. v

Acknowledgements........................................................ vi

Chapter 1: General Background and Purpose..................................... 1

Chapter 2: Variation in ribbed mussel populations along nitrogen-loading gradient in Narragansett Bay......................................................... 27

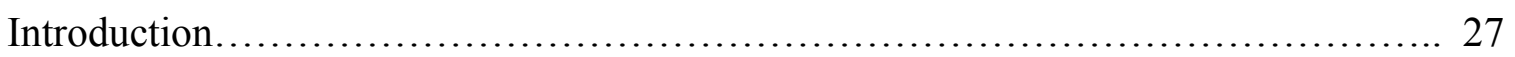

Materials and Methods................................................ 30

Results.............................................................. 32

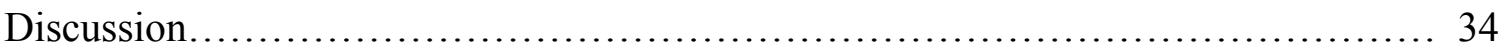

References........................................................... 38

Tables and Figures.................................................... 43

Chapter 3: Growth of ribbed mussels in Narragansett Bay.......................... 52

Introduction......................................................... 52

Materials and Methods................................................ 55

Results.............................................................. 58

Discussion............................................................. 61

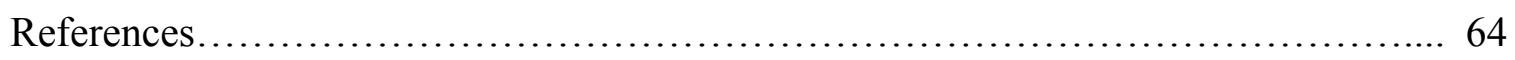

Tables and Figures................................................. 67

Chapter 4: Conclusions and Final Thoughts.................................. 77 


\section{LIST OF FIGURES}

Figure 1.1: Map of Narragansett Bay, Rhode Island ................................. 22

Figure 1.2: Watershed area of Narragansett Bay, Rhode Island ....................... 23

Figure 1.3: Salt marsh vegetation zonation patterns................................. 24

Figure 1.4: Map of Providence River showing locations of Bucklin Point and Field's Point WWTFs, the two major WWTFs in Rhode Island................................... 25

Figure 1.5: Nitrogen cycling in salt marsh habitats.................................. 26

Figure 2.1: Map of Narragansett Bay, Rhode Island picturing the three chosen salt marshes analyzed in this study ............................................................... 49

Figure 2.2: GSI values pooled by sites and compared by sampling month......................... $\quad 50$

Figure 2.3: GSI values for the month of June compared by site....................... 51

Figure 3.1: External growth bands of Geukensia demissa ................................................... 73

Figure 3.2: External shell erosion on G. demissa shell ............................... 74

Figure 3.3: Size frequency distribution of G. demissa at A) Apponaug, B) Passeonkquis, and C)

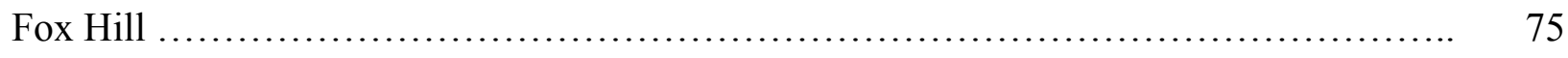

Figure 3.4: Linearized von Bertalanffy growth equation ............................ 76 


\section{LIST OF TABLES}

Table 2.1: Salt marsh nitrogen loading characteristics for Apponaug, Passeonkquis, and Fox Hill.

Table 2.2: Porewater nitrogen concentrations at the three salt marshes for the summer of 2012.

Table 2.3: Average density and biomass of $G$. demissa populations 45

Table 2.4: Average condition index of G. demissa populations 46

Table 2.5: Historical comparison of density and biomass of G. demissa populations in Narragansett Bay, RI

Table 3.1: Salt marsh nitrogen loading characteristics for Apponaug, Passeonkquis and Fox Hill.

Table 3.2: Porewater nitrogen concentrations of the three salt marshes for the summer of 2012 .

Table 3.3: Comparison of growth rates among size classes of mussels at each site from 20072012

Table 3.4: Average annual growth rate of direct growth analysis for $2012-2013 \ldots \ldots \ldots \ldots . \quad 70$

Table 3.5: $K$ and $L_{\infty}$ values of direct growth analysis 


\section{ACKNOWLEDGEMENTS}

\section{CONTRIBUTIONS TO THE RESEARCH CONTAINED WITHIN THIS THESIS:}

Chapter 2: Kyle Schoolcraft, Mike Martel, Nicole Cote, Cindy Cesar, C.J. Pickett, and Darrin James helped with sampling and data collection. Dr. Serena Moseman- Valtierra and lab made the collections of porewater nitrogen concentrations.

Chapter 3: Dr. M. M. Chintala provided guidance for the growth band analysis procedures

\section{PROFESSIONAL ACKNOWLEDGEMENTS:}

First and foremost I would like to express my upmost appreciation to Dr. Breea Govenar for her unwavering support and continual motivation throughout these past two years. I thank her for the opportunity to participate in this fascinating and important line of research and for her professional guidance. Without her constant advice and "pom-poms", I would have been lost and this thesis would not have been possible.

Thanks also to my committee members, Dr. Thomas Meedel, Dr. Marita Sheridan, Dr. Eric Roberts, and Dr. Sarah Knowlton for thought-provoking advice, discussions, and contributions.

The work in this thesis was supported by an award from the Rhode Island Research Alliance/Science and Technology Council to Serena Moseman-Valtiera and Breea Govenar by the National Science Foundation EPSCoR Cooperative Agreement \#EPS-1004057 and the State of Rhode Island. A Rhode Island NSF EPSCoR research assistantship stipend provided me critical support during both of my years in the Master's Program without which I would have been unable to complete my thesis in such a timely manner.

\section{PERSONAL ACKNOWLEDGEMENTS:}

I am forever thankful to the support received from my friends in the lab and outside: Sabrina, Sara, Katerina, Eric, and Cynthia. You all supported me in my times of need and kept me sane at times when I thought I might lose my mind.

My family, all of you stood by my side during this pursuit and all other previous adventures in my life. My grandparents always cheered me on when I needed some encouragement. And my parents and brother, you allowed me to take over the dining room table during the process of writing my thesis and constantly motivated and supported me to strive for my best.

Alek, you put up with my constant outbursts, stressful moods, and downright craziness during this entire process. You were always by my side supporting me and I love you dearly for your patience. 


\section{Chapter 1}

\section{General Background and Purpose}

Shoreline ecosystems have been impacted both positively and negatively by anthropogenic influences since the Industrial Revolution. Humans have historically colonized near waterways to facilitate trade and as a result, by-products and waste from expanding human populations have impacted many rivers, bays, and coastlines. Since the European settlement of Narragansett Bay (Rhode Island) in 1524, human populations have been increasing and expanding (Nixon et al. 2008). Human activities have caused local and global changes, including elevated temperatures, sea level rise, ocean acidification, and nitrogen loading (e.g. Smith 2010, Nicholls 2011, Beaugand 2012, Anisfeld and Hill 2012). All of these alterations within these coastal systems have also affected Narragansett Bay (e.g. Pilson 2008, Church 2011, Anisfeld and Hill 2012). Nitrogen loading is significant as it is changing many aspects of estuarine systems, increasing biomass of producers, decreasing oxygen concentrations (hypoxia), elevating greenhouse gas emissions, and stimulating nuisance and toxic algal blooms (e.g. Oviatt 2008, Saarman et al. 2008, Higgins 2013, Smayda and Borkman 2008). The ribbed mussel, Geukensia demissa, forms dense aggregations within the fringing salt marshes of Narragansett Bay and has been shown to respond predictably to increasing anthropogenic changes, displaying increases in biomass, density, and physiological condition in marshes with greater nitrogen loads (Chintala et al. 2006). In my thesis, I am investigating the variation in $G$. demissa populations along a nitrogen-loading gradient in salt marshes of Narragansett Bay, RI to further observe the responses of these ribbed mussel populations and to establish a baseline to which comparisons can be made after efforts to reduce nitrogen loading. 


\section{Narragansett Bay}

Narragansett Bay is the most conspicuous feature in the state of Rhode Island, contributing more than $544.9 \mathrm{~km}$ of coastline to a state that is only $1,214 \mathrm{~m}^{2}$ (Figure 1.1; Boothroyd and August 2008) and is fed by a watershed encompassing $2066 \mathrm{~km}^{2}$ of land in both Massachusetts and Rhode Island (Figure 1.2). Narragansett Bay is an estuary, a semi-enclosed coastal body of water, which experiences a mixing of saltwater from Rhode Island Sound and freshwater from rivers including the Woonasquatucket, Moshassuck, Blackstone, Seekonk, and Providence Rivers. Narragansett Bay is characterized by two branches referred to as the East and West Passages (Kincaid et al. 2008). Saltwater enters this estuary mainly through the East Passage, circulates into the Upper Bay and Mount Hope Bay, and then exits towards Rhode Island Sound through the West Passage (Pilson 1985, Kincaid et al. 2008, Spaulding and Swanson 2008). The composition and dynamics of the freshwater from terrestrial runoff and rivers, and seawater from the ocean impacts the water quality of Narragansett Bay. Good water condition in Narragansett Bay is important to Rhode Island both ecologically and economically. The Bay supports many commercially important species including finfish, lobsters, clams, and oysters (Rorholm and Farrell 1992), and healthy beaches support the $\$ 5.2$ billion tourism industry, contributing as many as 41,000 jobs for the state (RIDEM News 2012).

Narragansett Bay exhibits steep environmental gradients including ranges in temperature, salinity, and nutrient concentrations, which vary hourly due to diurnal tidal fluxes (Saarman et al. 2008, Kincaid et al. 2008, Deacutis 2008, Oviatt 2008). Generally, the Upper Bay has lower salinity and higher temperatures and nutrient concentrations than the lower bay, which has direct seawater inputs from Rhode Island Sound and greater average depths (16-48 km) compared to the Upper Bay (6-16 km) (Pilson 1985, Nixon et al. 1995, Kincaid et al. 2008, Saarman et al. 
2008, Deacutis 2008). Nutrients, including nitrogen and phosphorous, derived from the rivers in the watershed, stimulate primary and secondary production within the estuary, but nutrients derived from human activities can also "tip the balance" and add an excess of nutrients in the Upper Bay (e.g. Oviatt et al. 2008).

\section{Salt Marshes}

Narragansett Bay has many different fringing coastal habitats, including rocky shores, seagrass beds, and salt marshes. Salt marshes account for more than 600 ha of the shoreline and play many important ecological roles including water quality maintenance, erosion and flood control, and serve as habitat and food sources to fish and wildlife (Teal and Howes 2000, Wigand et al. 2001, Deegan et al. 2002, Wigand 2008). Saltwater flushes into the marshes daily during diurnal tides along with mixing of freshwater from river inputs. This mixing of freshwater and saltwater contributes to high rates of productivity with inputs of local nutrients from freshwater (Nixon 1997).

Salt marshes of Narragansett Bay experience high amounts of seasonal variation due to their location in the northeastern United States. Harsh winters in the northeast can cause ice damage with sheets of ice covering areas of the marsh. These sheets of ice can rip tufts of grasses from the marsh, resulting in floating rafts of dead plant material (wrack) that may potentially wash up onto other areas of the marsh and bury vegetation (Bertness 2007). New England marshes are also characterized by a heavy peat substrate (Nixon and Oviatt 1973) and tend to be small in area. This differs from marshes found in the southeast, where the salt marshes are characterized by mineral sediments typical of a nonglaciated area. The marshes in the southeast are also much larger. These differences in sediment loads create differences in marsh elevation, 
tidal currents, and wave motion (Boothroyd and August 2008). Unlike the northeast marshes, salt marshes in the southeast also do not experience the same seasonal variations.

In Narragansett Bay, like other well-studied marshes in the Meadowlands (NJ), Long Island Sound (NY and CT), Buzzard's Bay (MA), Waquoit Bay (MA) and Plum Island LongTerm Ecological Research Station (MA), the salt marshes are divided into zones characterized by the dominant plant species. The vegetative zonation patterns observed in these coastal salt marshes show changes in species composition and density from low to high intertidal distances. The low marsh bordering the water, is dominated by the halophilic marsh cordgrass Spartina alterniflora. There are two forms of this cordgrass, a short and a tall form. The primary productivity of the short form of this cordgrass is generally nitrogen-limited, while the tall form is not (Bertness 2007). Upland from the water's edge, S. alterniflora is replaced by the marsh hay $S$. patens, which has lower salt tolerance and is found at areas of the marsh that are not flooded by tides (Bertness 2007) (Figure 1.3).

Human activities have significant impacts on coastal ecosystems. Draining, filling, diking and ditching have reduced the extent of wetland ecosystems in the United States by over 50\% (Wigand 2008). In Rhode Island, 53\% of the coastal wetlands were lost between the 1700s and 1900s (Valiela et al. 1997, Deegan et al. 2002), diminishing the ecosystem services provided by healthy marshes. For example, unperturbed coastal marshes stabilize sediments and increase dense grass coverage, which reduce the impact of incoming storm waves, protecting the shoreline from erosion. The water uptake and holding capacity of salt marshes also reduce the extent of storm surges (Barbier et al. 2011). The dense grass coverage of marshes slows the movement of water through these areas. Subsequently, the suspended sediments in the water are 
deposited on the surface of vegetation within the marsh, facilitating grass nutrient uptake and effectively filtering the water of particulate matter (Morgan et al. 2009).

Detrital matter has historically been considered to be the primary source of energy in salt marsh food webs. An annual ecological energy budget for New England salt marshes indicated that consumption exceeds production in these systems, making detritus very important as an energy source (Nixon and Oviatt 1973). High inputs of nutrients into these salt marshes, however, shift the food web from one based on detritus towards one based on phytoplankton (e.g. Oviatt et al. 2008). In contrast, marsh plants are typically not a significant source of nutrition and are protected from grazers by tough cellulose and silica in the plant material that make this visually dominant vegetation unpalatable to herbivores. Due to the characteristics of salt marsh food webs, the primary faunal composition includes detritivores, filter feeders, and predators (e.g. marsh snails, ribbed mussels, and fiddler crabs) (Bertness 2007).

\section{Geukenisa demissa}

Geukensia demissa, the ribbed mussel, is the biomass-dominant benthic invertebrate within eastern salt marshes, from Georgia to southern areas of Canada (Kuenzler 1961, Jordan and Valiela 1982, Bertness and Grosholz 1985, Chintala et al. 2006). The ribbed mussel is a foundation species in salt marshes, creating complex habitats that facilitate colonization for conspecifics and other organisms, including plants, and smaller invertebrates, such as snails and barnacles (Kuenzler 1961, Angelini 2011, and Altieri et al. 2007). The benefits to other species; however, are not limited to physical architecture of the mussels. The ribbed mussels provide the cordgrass with additional nitrogen by transforming the organic particulate matter from the water column into dissolved forms as feces and pseudofeces that can be utilized by the plant (Jordan 
and Valiela 1982, Bertness 1984). By providing nutrients to S. alterniflora, dense aggregations of G. demissa increase growth of the marsh cordgrass. Conversely, S. alterniflora directly increases growth and survivorship of $G$. demissa by means of physical protection and greater area for settlement, as such as indirectly slowing water currents into the marsh. Retaining sediment prevents erosion and decreases vulnerability of the ribbed mussels to physical disturbances (Bertness 1984). Marsh cordgrass increases the oxygen content of the sediment that is available to the ribbed mussel population living there (Howes et al. 1981). Aggregations of mussels, however, have positive and negative effects on conspecifics. The cost is smaller individual shell length due to increased intraspecific competition for food and space, while the benefits include increased success of fertilization, protection from predation and thermal stress, and increased attachment strength due to their combined byssal thread formations (Bertness and Grosholz 1985).

The physiology and reproductive success of ribbed mussels depends on the availability and quality of food available. As a filter-feeder, G. demissa feeds primarily during periods of high-tide, coupling the benthos to the water column by filtering the water that enters the marsh during a tidal cycle (Bertness 2007). G. demissa feed on seston, which contains a mixture of natural organic material including phytoplankton, plant detritus, bacteria and other microorganisms (Kreeger and Newell 2001). However, the diet of G. demissa is composed primarily of phytoplankton and $S$. alterniflora detritus, and feeding rates are highest in the summer and autumn and lowest in winter and spring- corresponding with bloom times (Peterson et al. 1985, 1986; Kreeger et al. 1990; Langdon and Newell 1990). During the summer when food is abundant, mussels store glycogen that can be used in the winter or until food is available again. 
The availability of food has been shown to significantly increase the reproductive output and growth rates of ribbed mussels (Allen and Williams 2003, Clausen and Riisgård 1996, Evgenidou and Valiela 1982, Bayne 2004, Fearman et al. 2009). G. demissa is dioecious, having separate female and male individuals that reproduce by releasing their gametes into the water which then fertilize externally. Gamete production is dependent on diet with stored glycogen being utilized as an energy source during gametogenesis (Fearman et al. 2009). The amount of glycogen stored is regulated by the quantity of food since reproduction is a secondary energy allocation to the primary metabolic energy requirements. Once metabolism requirements are met, energy can then be assimilated to stored glycogen reserves for reproduction (Fearman et al. 2009). After gametes are released, fertilization success is dependent on density, following the Allee effect (reduced fertilization at low population densities and increased fertilization rates within high densities; Bertness 2007). Higher densities increase fertilization success because of a minimization of gamete dilution (Levitan et al 1992). Fertilized larvae then undergo a period of planktotrophic development, which terminates with settlement and metamorphosis into an adult form onto benthic substrates (Bayne et al. 1983). The quantity of food available to the larvae contributes to the survival and recruitment. With low levels of food, larvae may starve or experience prolonged development that make them more exposed to predation or exportation, whereas high levels of food stimulate larval growth (Bertness 2007). The recruitment of larvae is dependent on tidal fluxes as well as distribution of the adult sessile population. Recruitment has been found to be highest among larger adult populations (Bertness and Grosholz 1985, Nielsen and Franz 1995). Although filter-feeders can inadvertently prey on their own larvae, adult ingestion of larvae in the water column may actually enhance the settlement of larvae to mussel 
beds due to the filtration and deposition of larvae into the existing populations (Nielsen and Franz 1995).

Like reproduction and larval survivorship, individual growth of $G$. demissa has been shown to relate to food quantity, as well as variations in physiological condition, energy requirements, and age, resulting in highly variable growth rates (Evgenidou and Valiela 2002, Bayne 2004). Growth of the ribbed mussel is continuous throughout their lifetime (Sukhotin and Flyachinskaya 2009), although growth rate slows with an increase in age (Brousseau 1984, Evgenidou and Valiela 2002). Ribbed mussels grow predominately in the summer, laying down new shell (Kuenlzer 1961, Franz 2001, Bertness 2007). The resulting formation of growth rings has been used to determine age and analyze growth rates in other bivalves as well as this species (Brousseau 1984). Individual growth of G. demissa has also been shown to be density dependent, with growth rates being suppressed in high-density aggregations (Bertness and Grosholz 1985, Nielsen and Franz 1995). The reduction of growth is due to an increase in competition for space and resources, which decrease the rate of growth of the individual mussels. In controlled experiment, G. demissa growth responded to higher phytoplankton concentrations, and small mussels had higher growth rates than larger mussels (Allen and Williams 2003, Clausen and Riisgård 1996).

\section{Nutrient Loading}

Estuaries have been historically used as transportation and waste disposal, as well as providing coastline area for human development, all which have led to increased nutrient inputs into these bodies of water (Nixon et al. 2008). Addition of excess nutrients impacts can affect the entire ecosystem, including primary production levels, dissolved oxygen concentrations, and 
food web cycles (e.g. Pilson 1985, Nixon et al. 1995, Calbretta and Oviatt 2008, Kutcher 2009, Brush and Nixon 2010, Carmichael 2012).

In addition to freshwater inputs from rivers and groundwater, there are many anthropogenic sources of nutrients into Narragansett Bay, including wastewater treatment facilities (WWTFs), septic systems, agricultural runoff, and industrial waste (Nixon et al. 1995). Although all of these sources increase the phosphorous and nitrogen concentrations to the Bay, WWTFs contribute the highest percentage of total nutrient inputs (Pryor et al. 2007). There are two major WWTFs releasing nutrients into Narragansett Bay, Field's Point and Bucklin Point, which have total annual nitrogen loads of $7.6 \mathrm{mg} / \mathrm{L}$ and $6.4 \mathrm{mg} / \mathrm{L}$, respectively $(\mathrm{NBC} 2012)$. The location of these WWTFs contributes to the nutrient concentration gradient observed in the Bay. Located on the Providence River at the northern part of Narragansett Bay (Figure 1.4), these effluents enter the Bay in a greater concentration relative to the southern Bay, which experiences dilution from daily flushing from Rhode Island Sound.

Estuarine marshes may mitigate nitrogen runoff to the ocean due to their physical location between land and the estuary. However, high inputs of nitrogen into marsh systems alter the structure of the salt marsh including species composition, species density, primary and microbial production (e.g. Nixon 1980, Oviatt et al. 1986, Levine et al. 1998, Valiela 2000, Bertness et al. 2002, Davis et al. 2004, Deegan et al. 2007). Nitrogen that enters the marsh may be incorporated into plant biomass and recycled in the ecosystem, buried in the soil, or reduced to $\mathrm{N}_{2}$ and released into the atmosphere (Nowicki and Gold 2008). All life depends on nitrogen, but only a few organisms are able to transform $\mathrm{N}_{2}$ into ammonia $\left(\mathrm{NH}_{3}\right)$, which is then oxidized through nitrification into nitrite and then nitrate, which can be utilized by plants or converted back to $\mathrm{N}_{2}$ by a process called denitrification (Figure 1.5). The process of denitrification may 
reduce the impact of high nitrogen levels to coastal habitats and has been shown to be a significant nitrogen-sink in marsh sediments (Howes et al. 1996, Nowicki et al. 1999).

\section{Eutrophication Issues}

Increased nitrogen levels in estuaries leads to eutrophication and consequently higher rates of production and incidence of hypoxia and anoxia, elevated pathogen transmissions and greenhouse gas emissions, and shifts in animal community structure. Hypoxia and anoxia are caused by decomposing phytoplankton and macroalgal blooms. As these blooms decompose, bacteria feed off of the decaying matter and consume the available oxygen in the water column (Hauxwell et al. 2001, 2003, Nixon and Buckley 2002). This reduction in oxygen concentration in the water is harmful to nearly all species inhabiting the Bay, as oxygen is necessary for sustained life.

An example of a hypoxic event that was devastating to the Rhode Island shoreline occurred in Greenwich Bay, a sub-estuary of Narragansett Bay. In 2003, dissolved oxygen concentrations in the water column oxygen concentration fell below $3 \mathrm{mg} / \mathrm{L}$, reaching hypoxic conditions, resulting in a large "fish kill". Rhode Island Department of Environmental Management (RI DEM) estimated the kill to consist of approximately one million marine organisms, including small juvenile menhaden, small crabs, larger blue crabs, grass shrimp, blackfish, horseshoe crabs and American eels (RIDEM 2003). The phytoplankton that were suspended in the water started to decompose when the organisms utilized all of the available nutrients and light could no longer penetrate the water column, decreasing the amount of photosynthetic oxygen production. The decomposing blooms then further deplete oxygen levels as a result of bacteria breaking down the decaying phytoplankton (RIDEM 2003). 
Another effect of higher nitrogen loads into estuaries is shifts in the distribution and abundance of organisms. For example, in the nitrogen-loaded marshes of coastal New England, the distribution of plants in salt marshes has shifted toward greater coverage by S. alterniflora. With greater nitrogen loading, the densities of S. patens and short-S. alterniflora have decreased, but the density of tall-S. alterniflora has increased and eventually resulting in a shift of dominance within the marsh to tall-S. alterniflora (Valiela et al. 1975, Wigand et al. 2003). The base of the food web in salt marshes has also shifted, from reliance on plant detritus to greater input of macroalgae and phytoplankton (Kutcher 2009). Increased nitrogen loads may also increase insect herbivory of the marsh plants, resulting in decreased plant biomass due to consumer suppression of primary production (Bertness 2008).

The response of ribbed mussel populations depends on a balance between increased food availability, which impacts many aspects of their physiology, and alterations to the marsh, such as change in plant density and composition. In coastal marshes impacted by high nitrogen loads, G. demissa had increased shell and soft-tissue growth and decreased survival, potentially due to higher increased food availability caused by the increased nutrient inputs (Carmichael 2012). In Waquoit Bay, MA, G. demissa exhibited an increase in shell growth of juveniles, as well as a reduced shell growth in adults (Feinstein et al. 1996, Evgenidou and Valiela 2002). Similarly, in Narragansett Bay increased the biomass and abundance of ribbed mussels were higher in highly nitrogen-loaded salt marshes (Chintala et al. 2006).

\section{Recent Changes to Narragansett Bay}

Since the Clean Water Act in 1977, politicians, scientists, and the general public of Rhode Island have become aware of the need to restore the water quality of Narragansett Bay. 
One recent initiative to reduce anthropogenic inputs of nutrients into Narragansett Bay was the Narragansett Bay Commission CSO Abatement Project. CSOs, or combined sewer overflows, were originally designed to collect rainwater, domestic sewage and industrial wastewater to be transported to one of the WWTFs. However, the capacity of the sewer systems was not large enough to hold large amounts of wastewater during periods of heavy rainfall or snowmelt. The untreated wastewater overflow was then deposited into nearby bodies of water, polluting these rivers and ultimately Narragansett Bay with high levels of nutrients, metals, chemicals, and fecal matter. In November 2008, the first phase of the CSO Abatement Project was completed. This involved the construction of a $26 \mathrm{ft}$. diameter, three mi. long tunnel under the city of Providence to capture the overflow from 12 CSOs in the Field's Point collection area. Now, the captured wastewater is then transported to Field's Point (East Providence), where it is treated before being deposited into Providence River. The implementation of this network of CSOs has resulted in a decrease of dissolved inorganic nitrogen (DIN) and total nitrogen (TN) loading from Field's Point. There are three phases proposed for this project, the second phase is currently being installed and the third phase is expected to begin in 2017. These changes are predicted to reduce the negative impacts of nutrient loading on the ecosystem and human populations of Narragansett Bay.

\section{Topic of Thesis}

The physical location and biological characteristics of Geukensia demissa expose them to wide ranges in temperature, salinity, and nutrient concentrations, making them ideal models to observe the long-term impacts of nutrient enrichment on estuarine marshes (Weisberg et al. 1997, Levin 2000, Rosenberg 2001). Ribbed mussels have been used as environmental indicators because they respond predictably to high levels of environmental stress, mirroring increases in 
nitrogen loads by exhibiting increases in biomass, density, and growth (Dauer 1993, Tapp et al. 1993, Levin 2000, Chintala et al. 2006, Evgenidou and Valiela 2002, Calabretta and Oviatt 2008), and nitrogen stable isotope signatures of $G$. demissa tissues reflect the sources of anthropogenic nitrogen into these marsh habitats, with increased $\delta^{15} \mathrm{~N}$ levels that are derived from wastewater (McKinney et al. 2001). One unaddressed question is whether the link between nitrogen loading and food availability with the subsequent increase in size and abundance is due to greater energy investment into growth or fecundity, to population dynamics, such as an increase in recruitment or a decrease in mortality, or to a combination of mechanisms.

For my thesis, I have investigated the populations of ribbed mussels within three salt marshes along the nitrogen-loading gradient in Narragansett Bay, RI. My primary hypothesis is that with increased levels of nitrogen, higher levels of primary production are expected to increase food availability and subsequently increase the density, biomass and condition index of the mussels, as well as the individual growth and fecundity. I characterized the ecology of the three mussel populations based on their density, biomass, and condition index during the summer of 2012. The individual growth and fecundity was also characterized for the mussel populations by calculating the growth rates and the gonadosomatic index. In addition to the spatial variations in the ribbed mussel populations attributed to nitrogen loading and other geomorphical characterizations of the marshes. Historical temporal differences were also observed and reflect the long-term effects of nutrient loading into the Bay. 


\section{References}

Allen, B.J., and Williams, S.L. (2003). Native eelgrass Zostera marina controls growth and reproduction of an invasive mussel through food limitation. Marine Ecology Progress Series 254: 57-67.

Altieri, A.H., Silliman, B.R., and Bertness, M.D. (2007). Hierarchical organization via a facilitation cascade in intertidal cordgrass bed communities. The American Naturalist 169(2): 195- 206.

Angelini, C., Altieri, A.H., Silliman, B.R. and Bertness, M.D. (2011). Interactions among foundation species and their consequences for community organization, biodiversity, and conservation. BioScience 61(10):782-789.

Anisfeld, S.C. and Hill, T.D. (2012). Fertilization effects on elevation change and belowground carbon balance in a Long Island Sound tidal marsh. Estuaries and Coasts 35:201-211.

Bayne, B.L., Salkeld, P.N., and Worrall, C.M. (1983). Reproductive effort and value in different populations of the marine mussel, Mytilus edulis. Oecologia 59(1): 18-26.

Bayne, B. L. (2004). Phenotypic flexibility and physiological tradeoffs in the feeding and growth of marine bivalve molluscs. Integrative and Comparative Biology 44(6): 425-432.

Barbier, E.B., Hacker, S.D., Kennedy, C., Koch, E.W., Stier, A.C., and Silliman, B.R. (2011). The value of estuarine and coastal ecosystem services. Ecological Monographs 81(2): 169-193.

Bertness, M. D. (1984). Ribbed mussels and Spartina alterniflora production in a New England salt marsh. Ecology 65(6): 1794-1807.

Bertness, M. D., Ewanchuk, P.J., and Silliman, B.R. (2002). Anthropogenic modification of New England salt marsh landscapes. Proceedings of the National Academy of Sciences 99(3): 13951398.

Bertness, M. D. and Grosholz, E. (1985). Population dynamics of the ribbed mussel, Geukensia demissa: the costs and benefits of an aggregated distribution. Oecologia 67(2): 192-204. 
Bertness, M. D. (2007). Atlantic Shorelines: natural history and ecology. Princeton University Press.

Bertness, M.D., Crain, C., Holdredge, C., and Sala, N. (2008). Eutrophication and consumer control of New England salt marsh primary productivity. Conservation Biology 22(1):131-139.

Beaugrand, G. (2012). Unanticipated biological changes and global warming. Marine Ecology Progress Series 445: 293-301.

Brousseau, D. J. (1984). Age and growth rate determinations for the Atlantic ribbed mussel, Geukensia demissa Dillwyn (Bivalvia: Mytilidae). Estuaries 7(3): 233-241.

Brush, M.J. and Nixon, S.W. (2010). Modeling the role of macroalgae in a shallow sub-estuary of Narragansett Bay, RI (USA). Ecological Modeling 221: 1065-1079.

Calabretta, C.J., and Oviatt, C.A. (2008). The response of benthic macrofauna to anthropogenic stress in Narragansett Bay, Rhode Island: A review of human stressors and assessment of community conditions. Marine Pollution Bulletin 56:1680-1695.

Carmichael, R.H., Shriver, A.C., and Valiela, I. (2012). Bivalve response to estuarine eutrophication: the balance between enhanced food supply and habitat alterations. Journal of Shellfish Research 31(1): 1-11.

Chintala, M. M., et al. (2006). Comparison of Geukensia demissa populations in Rhode Island fringe salt marshes with varying nitrogen loads. Marine Ecology Progress Series 329: 101-108.

Church, J.A., Gregory, J.M., White, N.J., Platten, S.M., and Mitrovica, J.X. (2011).

Understanding and projecting sea level change. Oceanography 24(2): 130-143.

Clausen, I., and Riisgård, H.U. (1996). Growth, filtration and respiration in the mussel Mytilus edulis: no evidence for physiological regulation of the filter-pump to nutritional needs. Marine Ecology Progress Series 141: 37-45.

Dauer, D.M. (1993). Biological criteria, environmental health and estuarine macrobenthic community structure. Marine Pollution Bulletin 26(5): 249-257.

Davis, J. L., Nowicki, B., and Wigand, C. (2004). Denitrification in fringing salt marshes of Narragansett Bay, Rhode Island, USA. Wetlands 24(4): 870-878.

Deacutis, C.F. (2008). Evidence of ecological impacts from excess nutrients in Upper Narragansett Bay. In Science of Ecosystem-based Management: Narragansett Bay in the $21^{\text {st }}$ Century, ed. Alan Desbonnet and Barry A Costa-Pierce, 349-283. New York: Springer. 
Deegan, L.A., Wright, A., Ayvazian, S.G., Finn, J.T., Golden, H., Rand Merson, R., and Harrison, J. (2002). Nitrogen loading from upland areas alters seagrass support of higher trophic levels. Aquatic Conservation: Freshwater and Marine Ecosystems 12:193-212.

Deegan, L.A., Bowen, J.L, Drake, D., Fleeger, J.W., Friedrichs, C.T., Galvan, K.A., Hobbie, J.E., Hopkinson, C., Johnson, D.S., Johnson, J.M., LeMay, L.E., Miller, E., Peterson, B.J., Picard, C., Sheldon, S., Sutherland, M., Vallino, J. and Warren, R.S. (2007). Susceptibility of salt marshes to nutrient enrichment and predator removal. Ecological Applications 17(5): S42-S63.

Evgenidou, A., and Valiela, I. (2002). Response of growth and density of a population of Geukensia demissa to land-derived nitrogen loading, in Waquoit Bay, Massachusetts. Estuarine, Coastal and Shelf Science 55:125-138.

Fearman, J., Bolch, C.J.S. and Moltschaniwsky, J. (2009). Energy storage and reproduction in mussels, Mytilus galloprovincialis: the influence of diet quality. Journal of Shellfish Research 28(2): 305-312.

Feinstein, N., Yelenik, S., McClelland, J., and Valiela, I. (1996). Growth rates of ribbed mussels in six estuaries subject to different nutrient loads. Biological Bulletin 191: 327-328.

Franz, D.R. (2001). Recruitment, survivorship, and age structure of a New York ribbed mussel population. Estuaries 24(3): 319-327.

Hauxwell, J., Cebrian, J., Furlong, C., and Valiela, I. (2001). Macroalgal canopies contribute to eelgrass (Zostera marina) decline in temperate estuarine ecosystems. Ecology 82(4):1007-1022.

Hauxwell, J., Cebrian, J., and Valiela, I. (2003). Eelgrass Zostera marina loss in temperate estuaries: relationship to land-derived nitrogen loads and effect of light limitation imposed by algae. Marine Ecology Progress Series 247:59-73.

Howes, B. L., Weiskel, P.K., Goehringer, D.D., and Teal, J.M. (1996). Interception of freshwater and nitrogen transport from uplands to coastal waters: the role of salt marshes. Estuarine Shores: Evolution, Environments and Human Alterations 287-310. John Wiley and Sons Ltd, New York, NY, USA.

Jordan, T. E. and I. Valiela (1982). A nitrogen budget of the ribbed mussel, Geukensia demissa, and its significance in nitrogen flow in a New England salt marsh. Limnology and Oceanography 27(1): 75-90.

Kincaid, C., Bergondo, D., and Rosenberger, K. (2008). The dynamics of water exchange between Narragansett Bay and Rhode Island Sound. In Science of Ecosystem-based Management: Narragansett Bay in the $21^{\text {st }}$ Century, ed. Alan Desbonnet and Barry A CostaPierce, 67-100. New York: Springer. 
Kreeger, D.A., Newell, R.I.E., and Langdon, C.J. (1990). Effect of tidal exposure on utilization of dietary lignocellulose by the ribbed mussel Geukensia demissa (Dillwyn) (Mollusca: Bivalvia). Journal of Experimental Marine Biology and Ecology 144: 85-100.

Kreeger, D.A., and Newell, R.I.E. (2001). Seasonal utilization of different seston carbon sources by the ribbed mussel, Geukensia demissa (Dillwyn) in a mid-Atlantic salt marsh. Journal of Experimental Marine Biology and Ecology 260: 71-91.

Kuenzler, E.J. (1961). Structure and energy flow of a mussel population in a Georgia salt marsh. Limnology and Oceanography 6(2): 191-204.

Kutcher, T.E. (2009). Human Impacts on Narragansett Bay In Narragansett Bay National Estuarine Research Reserve: An Ecological Profile of the Narragansett Bay National Estuarine Research Reserve, ed. K.B. Raposa and M.I. Schwartz, Rhode Island Sea Grant, Narragansett, RI 176 pp.

Langdon, C.J. and Newell, R.I.E. (1990). Utilization of detritus and bacteria as food sources by two bivalve suspension-feeders, the oyster Crassostra virginica and the mussel Geukensia demissa. Marine Ecology Progress Series 58: 299-310.

Levin, L.A. (2000). Polychaetes as environmental indicators: Response to low oxygen and organic enrichment. Bulletin of Marine Science 61(1):668.

Levine, J. M., et al. (1998). Nutrients, competition and plant zonation in a New England salt marsh. Journal of Ecology 86(2): 285-292.

Levitan, D. R., et al. (1992). How distribution and abundance influence fertilization success in the sea urchin Strongylocentotus franciscanus. Ecology 73(1): 248-254.

McKinney, R.A., Nelson, W.G., Charpentier, M.A., and Wigand, C. (2001). Ribbed mussel nitrogen isotope signatures reflect nitrogen sources in coastal salt marshes. Ecological Applications 11(1):203-214.

Narragansett Bay Commission. (2012). Narragansett Bay Commission 2012 Data Report. Retrieved June 10, 2013 from Narragansett Bay Commission website: (http://snapshot.narrabay.com/app/Services/MossFile.ashx?file=/SiteDirectory/general/devblog/ snapshot/Documents/EMDA\%20Data\%20Reports/2012\%20NBC\%20Annual\%20Data\%20Repo rt.pdf).

Nicholls, R. J. (2011). Planning for the Impacts of Sea Level Rise. Oceanography 24(2): 144157.

Nielsen, K. J., and Franz, D. R. (1995). The influence of adult conspecifics and shore level on recruitment of the ribbed mussel Geukensia demissa (Dillwyn)."Journal of Experimental Marine Biology and Ecology 188: 89-98. 
Nixon, S.W. (1997). Prehistoric nutrient inputs and productivity in Narragansett Bay. Estuaries 20(2): 253-261.

Nixon, S.W. (1980). Between coastal marshes in coastal waters- a review of twenty years of speculation and research on the role of salt marshes in estuarine productivity and water chemistry. Estuarine and Wetland Processes with Emphasis on Modeling 437-523. Plenum, New York, NY, USA.

Nixon, S. W., Graner, S.L., and Nowicki, B.L. (1995). An assessment of the annual mass balance of carbon, nitrogen, and phosphorus in Narragansett Bay. Biogeochemistry 31(1): 15-61.

Nixon, S.W., and Buckley, B. (2002). “A strikingly rich zone”-nutrient enrichment and secondary production in coastal marine ecosystems. Estuaries 25(4b):782-796.

Nixon, S.W. and Oviatt, C.A. (1973). Ecology of a New England salt marsh. Ecological Monographs 43(4):463-498.

Nixon, S.W., Buckley, B.A., Granger, S.L, Harris, L.A., Oczkowski, A.J., Fulweiler, R.W., and Cole, L.W. (2008). "Nitrogen and phosphorus inputs to Narragansett Bay: past, present, and future" In Science of Ecosystem-based Management: Narragansett Bay in the $21^{\text {st }}$ Century, ed. Alan Desbonnet and Barry A Costa-Pierce, 101-175. New York: Springer.

Nowicki, B., Requintina, E., Van Keuren, D., and Portnoy, J. (1999). "The role of sediment denitrification in reducing groundwater-derived nitrate inputs to Nauset Marsh Estuary, Cape Cod, Massachusetts." Estuaries 22:245-259.

Nowicki, B.L. and Gold, A.J. (2008). "Groundwater nitrogen transport and input along the Narragansett Bay coastal margin” In Science of Ecosystem-based Management: Narragansett Bay in the $21^{\text {st }}$ Century, ed. Alan Desbonnet and Barry A Costa-Pierce, 67-100. New York: Springer.

Oviatt, C. A., Keller, A.A., Sampou, P.A., and Beatty, L.L. (1986). Patterns of productivity during eutrophication: a mesocosm experiment. Marine Ecology Progress Series 28: 69-80.

Oviatt, C.A. (2008). Impacts of nutrients on Narragansett Bay: A gradient approach. In Science of Ecosystem-based Management: Narragansett Bay in the $21^{\text {st }}$ Century, ed. Alan Desbonnet and Barry A Costa-Pierce, 523-544. New York: Springer.

Peterson, B.J., Howarth, R.W., and Garritt, R.H. (1985). Multiple stable isotopes used to trace the flow matter in estuarine food webs. Science 227: 1361-1363.

Peterson, B.J., Howarth, R.W., and Garritt, R.H. (1986). Sulfur and carbon isotopes as tracers of salt-marsh organic matter flow. Ecology 67: 865-874. 
Pilson, M.E.Q. (1985). Annual cycles of nutrients and chlorophyll in Narragansett Bay, Rhode Island. Journal of Marine Research 43: 849-873.

Pruell, R.J., Taplin, B.K., Lake, J.L, Jayaramna, S. (2006). Nitrogen isotope ratios in estuarine biota collected along a nutrient gradient in Narragansett Bay, Rhode Island, USA. Marine Pollution Bulletin 52: 612-620.

Pryor, D., Saarman, E., Murrary, D., and Prell, W. (2007). Nitrogen loading from wastewater treatment plants to upper Narragansett Bay. Narragansett Bay Estuary Program Report Univ. of RI Coastal Institute, Narragansett, RI, USA.

Rhode Island Departments of Environmental Management. (2003). The Greenwich Bay Fish Kill- August 2003: Causes, Impacts, and Responses. Retrieved June 102013 from RIDEM website: http://www.dem.ri.gov/pubs/fishkill.pdf

Rhode Island Departments of Environmental Management (2012). DEM praises Rhode Island voters for approving environmental bonds to preserve water quality, open space, farmland, and boost recreation development opportunities across the state. Retrieved June 102013 from RIDEM website: http://www.dem.ri.gov/news/2012/pr/1107122.htm

Rorholm, N., and Farrell, J. (1992). Narragansett Bay and the surrounding economy. Current Report: Narragansett Bay Project 1-25.

Rosenberg, R. (2001). Marine benthic faunal successional stages and related sedimentary activity. Scientia Marina 65(2):107-119.

Saarman, E., Prell, W.L., Murray, D.W., and Deacutis, C.F. (2008) Summer bottom water dissolved oxygen in Upper Narragansett Bay. In Science of Ecosystem-based Management: Narragansett Bay in the $21^{\text {st }}$ Century, ed. Alan Desbonnet and Barry A Costa-Pierce, 325-348. New York: Springer.

Seitzinger, S.P. (2000). Scaling up: site specific measurements to global-scale estimates of denitrification. In Estuarine Science: a Synthetic Approach to Research and Practice. J.E. Hobbie (ed.) Island Press, Washington, DC, USA.

Smayda, T.J., and Borkman, D.G. (2008). Nutrient and plankton dynamics in Narragansett Bay. In Science of Ecosystem-based Management: Narragansett Bay in the $21^{\text {st }}$ Century, ed. Alan Desbonnet and Barry A Costa-Pierce, 431-484. New York: Springer.

Smith, L. M, Whitehouse, S. and Oviatt, C.A. (2010). Impacts of Climate Change on Narragansett Bay. Northeastern Naturalist 17(1): 77-90.

Spaulding, M.L., and Swanson, C. (2008). Circulation and transport dynamics in Narragansett Bay. In Science of Ecosystem-based Management: Narragansett Bay in the $21^{\text {st }}$ Century, ed. Alan Desbonnet and Barry A Costa-Pierce, 67-100. New York: Springer.

Sukhotin, A.A., Flyachinskaya, L.P. (2009). Aging reduces reproductive success in mussels Mytilus edulis. Mechanisms of Ageing and Development 130:754-761. 
Tapp, J.F., Shillabeer, N., Ashman, C.M. (1993). Continued observations of the benthic fauna of the industrialized Tees estuary. Journal of Experimental Marine Biology and Ecology 172:67-80.

Teal, J.M., and Howes, B.L. (2000). Salt marsh values: retrospection from the end of the century. In Concepts and Controversies in Tidal Marsh Ecology. 9-22. Weinstein, M.P., and Kreeger, D.A. (eds.), The Netherlands: Kluwer Publishers.

Valiela, I., Teal, J.M., and Sass, W.J. (1975). Production and dynamics of salt marsh vegetations and the effects of experimental treatment with sewage slude, biomass, production and species composition. Journal of Applied Ecology 12(3): 973-981.

Valiela, I., Collins, G., Kremer, J., Lajtha, K., Geist, M., Seely, B., Brawley, J., and Sham, C.H. (1997). Nitrogen loadings from coastal watersheds to receiving estuaries: new method and application. Ecological Applications 7: 358-380.

Valiela, I. Cole, M., McClelland, J., Hauxwell, J., Cebrian, J., and Joye, S. (2000). Role of salt marshes as a part of coastal landscapes In Concepts and Controversies in Tidal Marsh Ecology. 23-38. Weinstein, M.P., and Kreeger, D.A. (eds.), The Netherlands: Kluwer Publishers.

Weisberg, S.B., Ranasinghe, J.A., Dauer, D.M., Schaffner, L.C., Diaz, R.J., Frithsen, J.B. (1997). An estuarine benthic index of biotic integrity (B-IBI) for Chesapeake Bay. Estuaries 20(1):149158.

Wigand, C., Comeleo, R., McKinney, R., Thursby, G., Chintala, M., and Charpentier, M. (2001). Outline of a new approach to evaluate ecological integrity of salt marshes. Human and Ecological Risk Assessment 7: 1541-1554.

Wigand, C., McKinney, R.A., Charpentier, M.A., Chintala, M.M, and Thursby, G.B. (2003). Relationships of nitrogen loadings, residential development, and physical characteristics with plant structure in New England salt marshes. Estuaries 26(6): 1494-1504.

Wigand, C., McKinney, R.A., Chintala, M.M., Charpentier, M.A., and Groffman, P.M. (2004). Denitrification enzyme activity of fringe salt marshes in New England (USA). Journal of Environmental Quality 33: 1144-1151.

Wigand, C. (2008). Coastal salt marsh community change in Narragansett Bay in response to cultural eutrophication. In Science of Ecosystem-based Management: Narragansett Bay in the $21^{\text {st }}$ Century, ed. Alan Desbonnet and Barry A Costa-Pierce, 299-522. New York: Springer. 


\section{FIGURE LEGENDS}

Figure 1.1: Map of Narragansett Bay, RI. NOAA

http://www.st.nmfs.noaa.gov/nauplius/media/time-series/site_northwest-narragansett-bay-phy/

Figure 1.2: Map of Narragansett Bay, RI showing the watershed area. $60 \%$ of the land making up the watershed of Narragansett Bay is in Massachusetts and the other $40 \%$ is in Rhode Island. NBEP http://www.watershedcounts.org/

Figure 1.3: Salt marsh zonation from low to high intertidal distance to the woody border. Grass adapted from Bertness 2007

Figure 1.4: Location of Bucklin Point and Field's Point WWTF on Providence River. Relative nitrogen loading from 2006 is shown by the size of the red circles. From Pryor et al. 2007

Figure 1.5: Nitrogen cycling in salt marsh habitats. Organic nitrogen enters the marsh through runoff and waste. Once in the marsh, nitrification occurs transforming the nitrogen. This form of nitrogen then gets incorporated into the plant biomass, or gets denitrified and released as nitrogen gas. Grass illustration adapted from Bertness 2007 


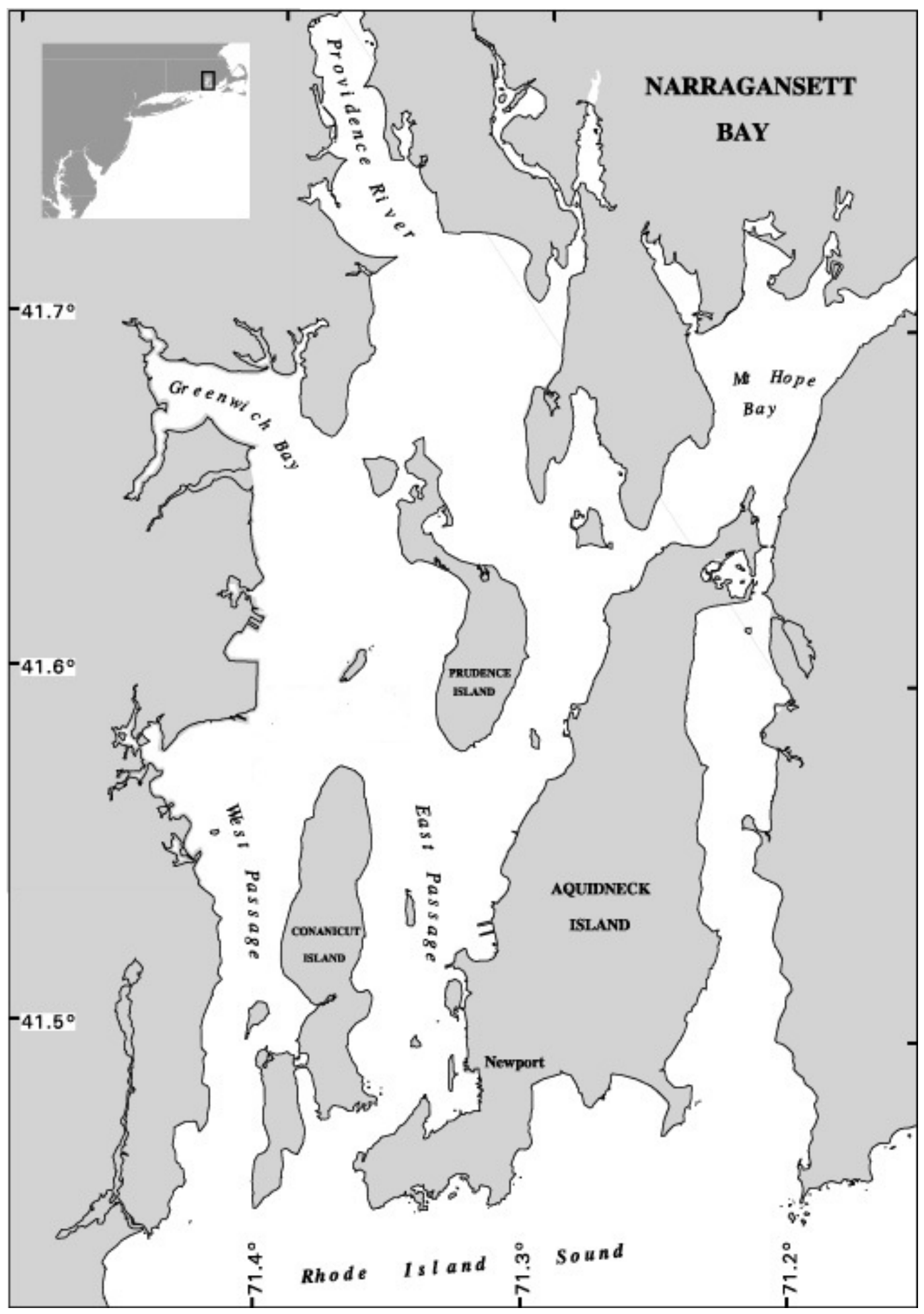

Figure 1.1 


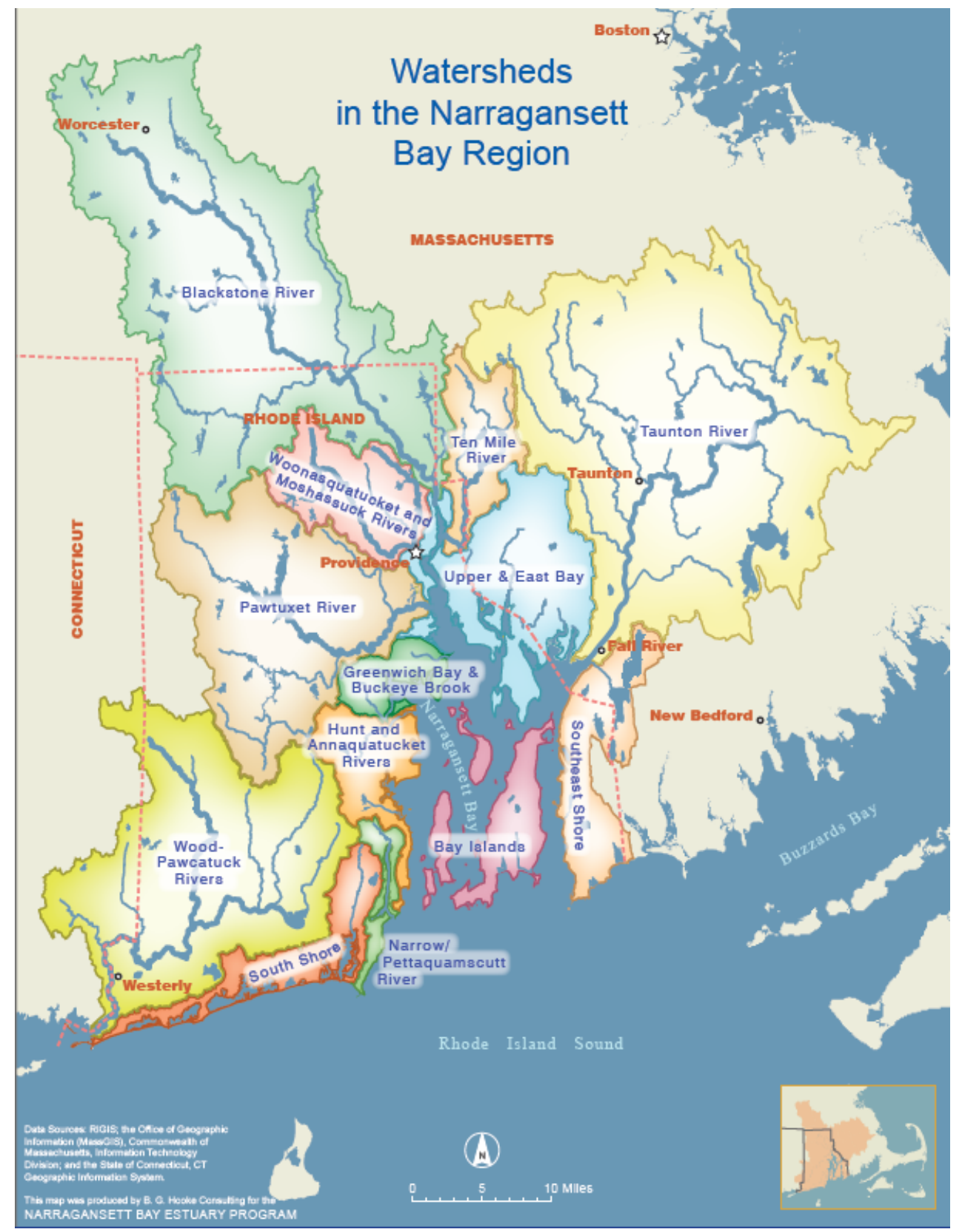

Figure 1.2 


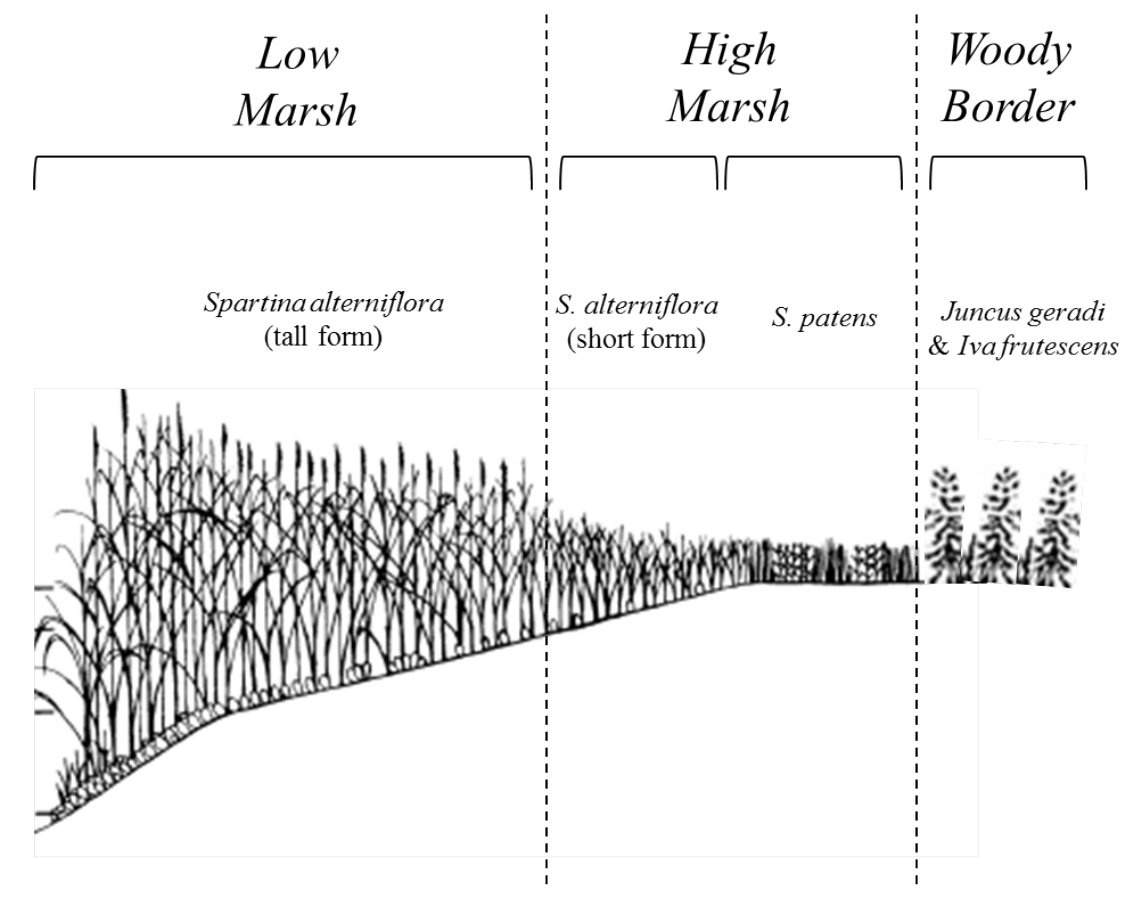

Figure 1.3 

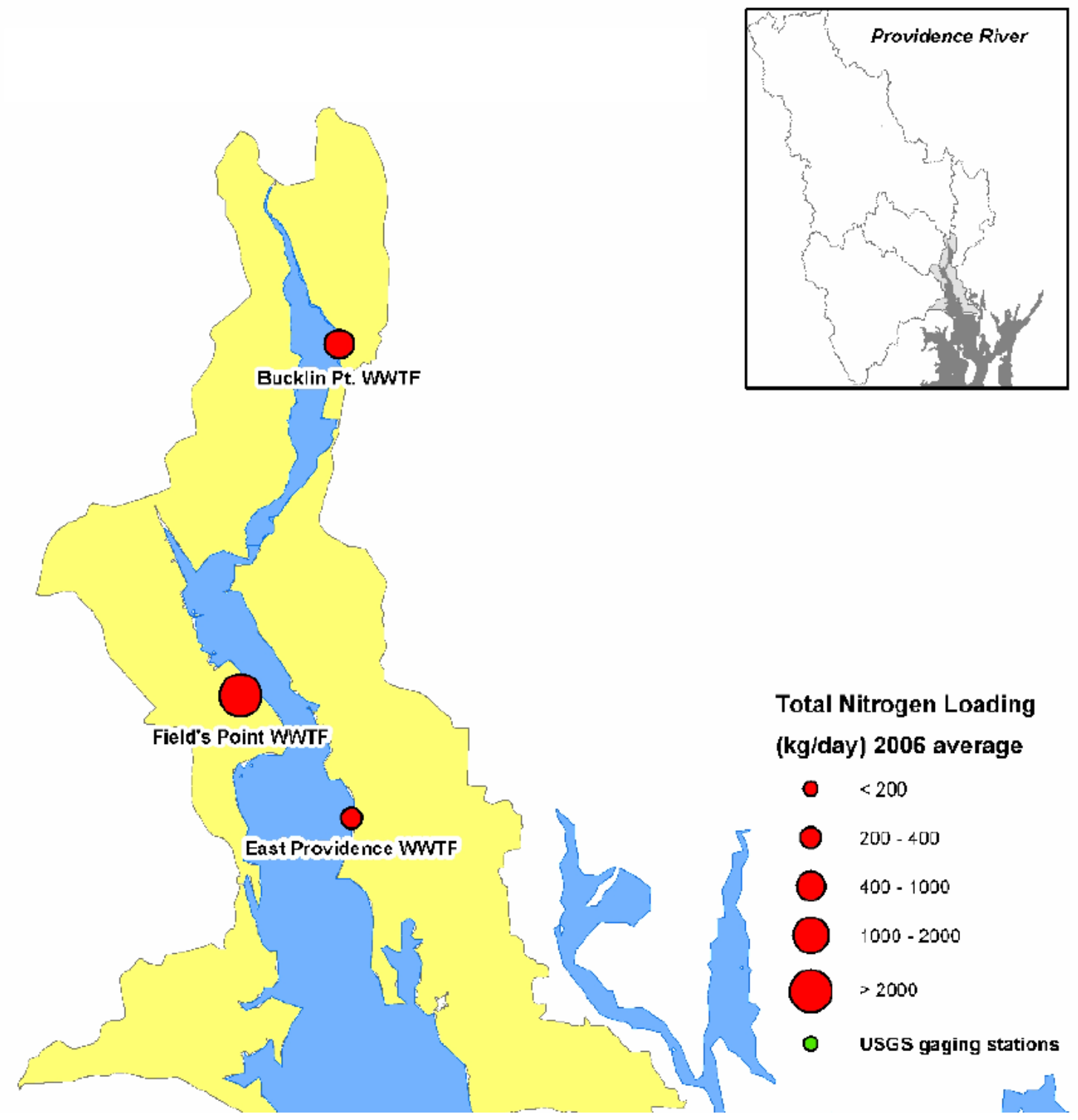

Total Nitrogen Loading (kg/day) 2006 average

- $<200$

O $200-400$

( $400 \cdot 1000$

( $1000-2000$

O $>2000$

O USGS gaging stations

Figure 1.4 


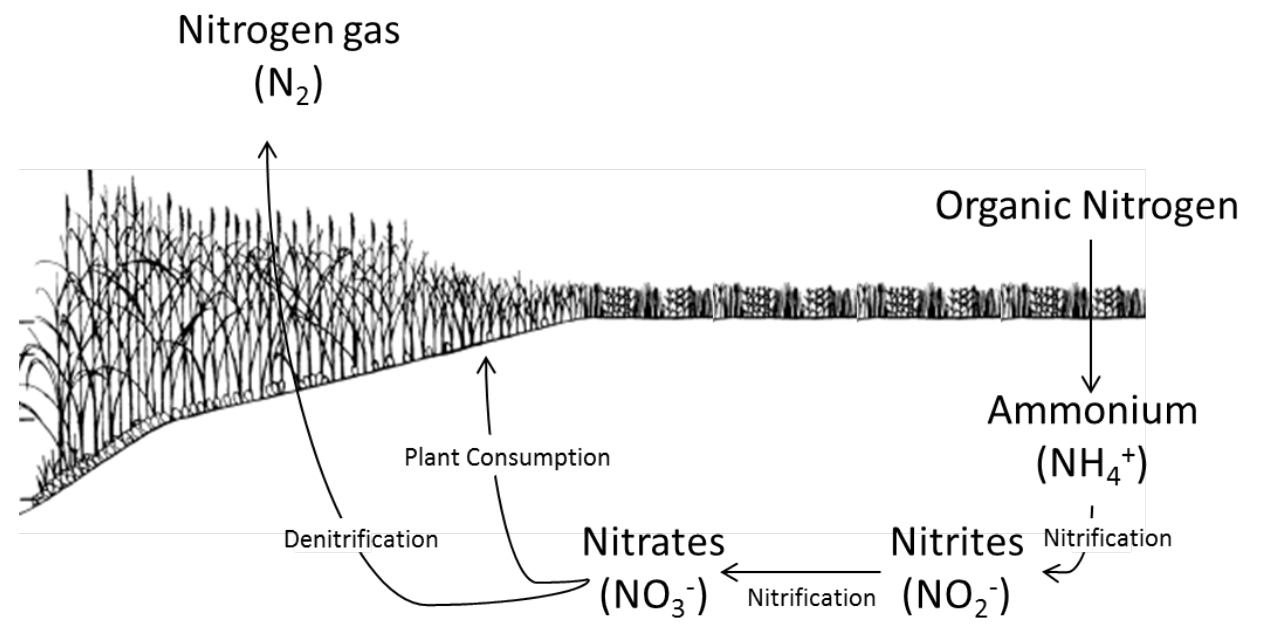

Figure 1.5 


\section{Chapter 2}

\section{Variation in ribbed mussel populations along a nitrogen-loading gradient in Narragansett Bay}

\section{INTRODUCTION}

Anthropogenic nutrient enrichment of estuaries significantly impacts the productivity of coastal ecosystems (Valiela et al. 1975, Nixon et al. 1984, Valiela et al. 1990, Wigand et al. 2004). Nitrogen is naturally limited in these waters, and an increase in nitrogen levels promotes high growth of phytoplankton and algae (Hauxwell et al. 2001, 2003, Granger et al. 2000, Nixon and Buckley 2002). This increase in primary production ultimately leads to a reduced dissolved oxygen content in the water and subsequent declines in the population of many organisms, including economically important fish and shellfish (Sfriso et al. 1992, D’Avanzo and Kremer 1994).

Narragansett Bay, a northeastern US estuary, has been undergoing nutrient loading since the Industrial Revolution (Nixon 1995). Industrialization and urbanization over the past 400 years has increased the nutrient concentrations entering Narragansett Bay leading to eutrophic conditions, increased algal blooms, and fish kills due to hypoxia (Valiela et al. 1990, Nixon 1995, RIDEM 2003). Although there are many sources that contribute to the nutrient enrichment, the primary source in the past century was Wastewater Treatment Facilities (WWTFs) (State of RI 2004, Pryor et al. 2006, NBC 2012). Two of the main WWTFs disposing into Narragansett Bay are located north of the Bay resulting in greater concentrations of nutrients entering the upper bay. In addition, the lower bay experiences daily flushing with seawater from Rhode Island Sound. This creates a north to south gradient of decreasing nutrient levels (Oviatt et al. 1981, Valente et al. 1992, Nixon et al. 1995). 
Narragansett Bay's fringing salt marshes are capable of potentially mitigating these increasing nitrogen levels (Oviatt et al. 1986, Levine et al. 1998, Bertness et al. 2002, Davis et al. 2004). The physical location of these marshes between land and water enables them to intercept some of the nutrient loading into Narragansett Bay, and microorganisms in the salt marshes actively transform nutrients by converting nitrate into $\mathrm{N}_{2}$ gas by the process of denitrification (Nixon 1980, Valiela 2000). This process has been shown to be a significant nitrogen sink in marsh sediments and may play a role in dampening the effect of nutrient loading on Narragansett Bay (Howes et al. 1996, Nowicki 1999). However, these salt marshes may have a limit of how much nitrogen can be mitigated, resulting in detrimental impacts to the marsh ecosystem by increases in nitrogen levels (Deegan et al. 2007).

The dominant benthic invertebrate in eastern salt marshes, Geukensia demissa, (Kuenzler 1961, Jordan and Valiela 1982, Bertness and Grosholz 1985) has been proposed as an environmental indicator species, due to their expectable responses to physical stress (Dauer 1993, Tapp et al. 1993, Levin 2000, Calbretta and Oviatt 2008). As filter feeders, they ingest the organic particles in the water, making them susceptible to changes in the water column such as increased food availability and pollutants. On the other hand, these mussels can withstand changes in stressors in their environment (Weisberg et al. 1997, Levin 2000, Rosenberg 2001). G. demissa has been found to be an indicator species of nitrogen levels within salt marshes because of their response to increased food availability and incorporation of anthropogenic sources of nitrogen. In Narragansett Bay marshes, the density and total biomass of ribbed mussels increased with nitrogen loads (Chintala et al. 2006) and in Waquoit Bay, ribbed mussels had higher growth and density with elevated nitrogen levels (Evgenidou and Valiela 2002). Furthermore, nitrogen stable isotope values within the tissue of this species have shown the 
greater $\delta^{15} \mathrm{~N}$ values are found in mussels inhabiting marshes with high anthropogenic wastewater inputs (McKinney et al. 2001, Pruell et al. 2006). However, it is unclear what the effects of reduced nitrogen levels would be on these ribbed mussel populations or how quickly the responses would be detected in this proposed indicator species.

In 2008, the Narragansett Bay Commission completed phase 1 of the Combined Sewer Overflow (CSO) Abatement Project, reducing the amount of wastewater entering Narragansett Bay by 4.6 billion gallons (NBC 2012). Phase 2 is expected to be completed by 2014 and will further reduce the amount of untreated wastewater entering Narragansett Bay. This change in the CSO has directly reduced the amount of nutrients that have entered Narragansett Bay and therefore, presumably, the amount entering salt marshes.

The purpose of this study is to establish a baseline to compare the density, biomass, physiological condition, and fecundity in mussel populations in Narragansett Bay salt marshes along a historic nitrogen-loading gradient. In addition, these ecological parameters are compared to mussels from the same sites in $1998-1999$, prior to the CSO installation, to determine if this species is responding to the lowered levels of wastewater inputs into Narragansett Bay. For this work, I hypothesized that density, biomass, physiological condition, and fecundity would increase with increasing nitrogen levels. In addition, I also hypothesized that when comparing these parameters to previous sampling years, that there would be an overall decrease in these populations following the reduced amount of wastewater entering these coastal habitats. 


\section{MATERIALS AND METHODS}

\section{Site locations and sampling}

Three salt marshes along Narragansett Bay, RI were selected as study sites, based on their historical nitrogen levels (Wigand et al. 2003; Figure 2.1, Table 2.1). These three sites reflect the north to south gradient of decreasing nutrient levels within the Bay with a high, an intermediate and a low nitrogen level site. Apponaug marsh, on the edge of a residential community and boating area, in Warwick, RI is documented to have a total marsh load of 10,253 $\mathrm{kg} \mathrm{N} \mathrm{ha}^{-1} \mathrm{yr}^{-1}$, Passeonkquis marsh, in a more protected cove in Warwick, RI has a total marsh load of 2,418 kg $\mathrm{N} \mathrm{ha}^{-1} \mathrm{yr}^{-1}$ and Fox Hill marsh on an undeveloped part of a state park in Jamestown, RI has a total marsh load of $10 \mathrm{~kg} \mathrm{~N} \mathrm{ha}^{-1} \mathrm{yr}^{-1}$ (Wigand 2003). Although south of Passeonkquis, Apponaug is exposed to more direct inputs of nitrogen within Greenwich Bay. Porewater concentrations of various forms of nitrogen (ammonia and nitrate and nitrite) were measured in this study at each of the salt marshes to determine current levels of nitrogen to these marshes (Table 2.2). The gradients remain for nitrate/nitrite with the lowest values at Fox Hill and highest values at Apponaug; however, for ammonia levels, Passeonkquis has the highest measured levels with Apponaug and then Fox Hill following with decreasing values.

Samples were collected June, July and August of 2012. At each of the marsh sites every month, 3-5 samples were collected using a $25 \mathrm{~cm} \mathrm{x} 25 \mathrm{~cm}\left(0.0625 \mathrm{~m}^{2}\right)$ sampling square. Collections were made near the marsh edge along tidal creeks at every site. All mussels and associated fauna were removed from the area and brought back to the laboratory on ice.

\section{Data Collection}

The density of the ribbed mussel population was compared among samples and calculated only as the number of mussels per meter squared. The observed number of individuals 
within the $25 \mathrm{~cm} \times 25 \mathrm{~cm}\left(0.0625 \mathrm{~m}^{2}\right)$ square was then multiplied to determine the amount of mussels within a squared meter $\left(\mathrm{n} \mathrm{m}^{-2}\right)$. Biomass was calculated as the amount of organic material among the individuals per square meter ( $\mathrm{g}$ AFDW $\mathrm{m}^{-2}$ ). Ash-free dry weight (AFDW) was obtained by weighing the total wet weight of an individual mussel, drying the tissue at $60^{\circ} \mathrm{C}$ for 48 hours, weighing the dry tissue, and then combusting the tissue at $500^{\circ} \mathrm{C}$ for 8 hours to obtain ash weight. The AFDW was calculated by subtracting the ash weight from the dry tissue weight. A conversion factor from wet weight to ash-free dry weight was calculated from a subset of individuals for each site and then used to determine ash-free dry weight for all other individuals. The biomass was then calculated for each sample by summing all of the individual biomass values within a sample and multiplying to calculate the biomass within a meter squared $\left(\mathrm{g}\right.$ AFDW m $\left.\mathrm{m}^{-2}\right)$

Condition index was calculated as: (Smith, 1985)

$$
\mathrm{CI}=\frac{\text { ash free dry weight }(\mathrm{g})}{\text { total shell volume }(\mathrm{mL})} \times 1000
$$

The shell volumes were measured with sand for each valve and then total shell volume was calculated by adding the volume of both valves.

Fecundity was measured using the Gonadosomatic Index (GSI) (Toro 2002). Mussels greater than $20 \mathrm{~mm}$ in length were analyzed to ensure reproductive maturity (Franz 1996). Both males and females were used for analysis, determined by the color of the gametes present in their mantle lobes: white mantle was identified as male and brown mantle was identified as female (Franz 1996). The mussel mantle was removed and weighed, and then the remaining tissue was removed to obtain the total tissue weight.

The GSI was calculated as: (Toro 2002)

$$
\mathrm{GSI}=\frac{\text { mantle weight }(g)}{\text { total tissue weight }(g)} \times 100
$$


For each site, for each month, 15-25 mussels were used to calculate individual GSI values.

\section{Statistics}

The CI data for all sites were transformed by applying an arcsine function to the original ratio $\left(\mathrm{g} \mathrm{mL}^{-1}\right)$ to approximate a normal distribution before statistical analysis was completed. Mussel biomass, density and condition index were analyzed with two-way analysis of variance (ANOVA) with a Tukey post-hoc test to determine significant differences amongst groups using SPSS software. Mussel GSI was log transformed to normalize the data before analysis by twoway and one-way ANOVA with a Tukey post-hoc to determine differences between groups. Correlations of GSI with sex, condition index, shell length, and shell volume were analyzed with non-parametric Spearman rank tests using SPSS software.

\section{RESULTS}

\section{Density and Biomass}

The ribbed mussel populations sampled across the nitrogen-loading gradient in Narragansett Bay salt marshes exhibited a large range in density and biomass values. Density ranged from 85.3 to $4448.0\left(\mathrm{n} \mathrm{m}^{-2}\right)$ and biomass ranged from 70.4 to $2280.0\left(\mathrm{~g} \mathrm{~m}^{-2}\right)$. Density was the highest at Apponaug with an average of $3928.9\left(\mathrm{n} \mathrm{m}^{-2}\right)$ over all samples and months. Mussel populations at Passeonkquis had an intermediate average density of $777.2\left(\mathrm{n} \mathrm{m}^{-2}\right)$ and the lowest average density of $97.8\left(\mathrm{n} \mathrm{m}^{-2}\right)$ at Fox Hill. Similarly, the biomass of mussels was also the highest at Apponaug with an average of all samples and months of $2121.6\left(\mathrm{~g} \mathrm{~m}^{-2}\right)$. Mussel populations had intermediate biomass values $\left(500.5 \mathrm{~g} \mathrm{~m}^{-2}\right)$ at Passeonkquis and the lowest average biomass (95.2 $\left.\mathrm{g} \mathrm{m}^{-2}\right)$ at Fox Hill (Table 2.3). 
No significant differences in biomass were detected between months. However, they were significantly different at each site when pooling all data for the three sampling months. The biomass was significantly higher at Apponaug than either Passeonkquis or Fox Hill ( $\mathrm{F}=38.12$, $\mathrm{p}<0.001)$.

\section{Condition Index}

Condition index (CI) of the mussels ranged from 32.28 to $74.88\left(\mathrm{~g} \mathrm{~L}^{-1}\right)$, with the highest $\mathrm{CI}$ at Apponaug and the lowest $\mathrm{CI}$ at Fox Hill. Mussels at Apponaug had an average CI of 70.39 ( $\left.\mathrm{g} \mathrm{L}^{-1}\right)$ over all months, whereas the average CI was $49.18\left(\mathrm{~g} \mathrm{~L}^{-1}\right)$ at Passeonkquis and $37.90(\mathrm{~g}$ $\mathrm{L}^{-1}$ ) at Fox Hill, over all months (Table 2.4).

CI values also varied significantly among months and sites $(\mathrm{F}=195.508, \mathrm{p}<0.001$; $\mathrm{F}=10.615, \mathrm{p}<0.00$; respectively). Mussels at Apponaug $(\mathrm{F}=10.376, \mathrm{p}<0.001)$ had a significantly higher $\mathrm{CI}$ in both June and August, compared to July ( $<<0.001$ and $\mathrm{p}<0.05$, respectively), but CI was not significantly different between June and August $(\mathrm{p}=0.384)$. Like at Apponaug, mussels at Fox Hill $(\mathrm{F}=8.848, \mathrm{p}<0.001)$ had significantly higher CI values in June and August than July with significant differences between June and July ( $<<0.001$ ), and July and August ( $<<0.05$ ), but not between June and August $(\mathrm{p}=0.995)$. In contrast, mussels at Passeonkquis $(\mathrm{F}=4.473, \mathrm{p}<0.05)$ had significantly higher CI values in July than August ( $<<0.05$ ). All other comparisons among months for Passeonkquis mussels were not significant.

\section{Gonadosomatic Index}

The mussels collected and analyzed for GSI from the three Narragansett Bay salt marshes, exhibited a range of 9.65 to 17.73 , smaller in magnitude than other bivalve species (Toro 2002). Among all sampling months and sites, GSI was weakly but negatively correlated with shell length $\left(r_{s}=-0.19, \mathrm{p}<0.05\right.$; Figure 4$)$ and condition index $\left(r_{s}=-0.286, \mathrm{p}<0.001\right.$; Figure 
5). The GSI and the sex of the mussels were not correlated, and GSI values were not found to be significantly different between male and female individuals among sampling sites and months (F $=0.277, p=0.600)$, among sites for all months $(F=0.722, p=0.488)$, or among months for all sites $(\mathrm{F}=1.138, \mathrm{p}=0.329)$.

There was little variation in GSI values among sites. Mussels at Passeonkquis had the highest average GSI (13.91 \pm 5.94$)$. The average GSI of mussels at Apponaug was slightly lower $(12.16 \pm 5.01)$ and the lowest at Fox Hill $(11.28 \pm 3.94)$. However, there were significant differences among sampling months and sites. Mussels at Passeonkquis had significantly higher GSI than Fox Hill in the month of June $(\mathrm{p}=0.007)$. All other comparisons (among sites) were not significant for the month of June. July and August showed no significant for any site comparisons for GSI.

\section{DISCUSSION}

Ribbed mussels occur along the creek bands of salt marshes, fringing Narragansett Bay. Due to their characteristics as sessile filter-feeders, ribbed mussels have been proposed as environmental indicators of historic nitrogen loading into the Bay. In 1998-1999, populations of ribbed mussels in Narragansett Bay increased in density and biomass, but not CI, with increasing levels of nitrogen in salt marshes. Following the installation of Phase I of the CSO in 2008, our results likewise demonstrate an increase in density and biomass, but CI also increased along the nitrogen-loading gradient. Given the expected increase in food availability with nitrogen loading, we also tested the hypothesis that fecundity would increase with nitrogen levels. While fecundity and nitrogen levels were significantly related in the ribbed mussel populations in June when gametogenesis occurs, there was neither a correlation between shell length or CI, nor significant 
differences in GSI between July or August. These results further support the conclusion that the higher GSI values in June resulted from gametogenesis and not from mussel health or energy available.

The fecundity patterns of these ribbed mussels were unexpected, not fitting with the hypothesis that mussels at Apponaug would exhibit greater fecundity as a result of the higher nitrogen loads. The greater amount of nitrogen available at Apponaug presumably stimulates the phytoplankton and algal growth, increasing the food availability to the ribbed mussel populations. With an increase in food, the mussels would have more energy to allocate to reproduction (Fearman et al. 2009). However, there were no significant differences in fecundity among the sites for July or August. June was the only month for which there were significant differences in GSI by site, with Passeonkquis having significantly higher GSI than Fox Hill. Temporal differences were also not expected as ribbed mussels within New England marshes, as mussels reproduce continuously with a spawning period from June-September (Jordan and Valiela 1982, Baez 2005). It is possible that Passeonkquis exhibited a higher fecundity in June due to increased levels of stored glycogen from the previous months, enabling them to have a higher reproductive output (Fearman et al. 2009). Stored glycogen is used as an energy source during gametogenesis with the quantity of stored glycogen influencing reproduction. When food is plentiful and energetic costs for metabolism are met, excess energy is stored in the form of glycogen for reproductive uses. Thus, the mussels at Passeonkquis may have experienced unusually high food availability at the end of the fall season before the mussels were able to spawn and therefore had a high amount of stored glycogen for reproduction.

When comparing data from this study to data collected at the same sites in 1999 (Chintala et al. 2006, Table 2.5), biomass and density measurements were higher in this study, suggesting 
that biomass and density are still increasing in response to nitrogen levels, despite the efforts to reduce nitrogen inputs into Narragansett Bay. One factor that could explain this result is if the primary source of nitrogen into these salt marshes is not derived from WWTFs, but groundwater or terrestrial runoff are playing a relatively more important role. This would correlate with nitrogen budgets for shallow embayments which suggest that $80 \%$ of nitrogen loading is from groundwater (Nowicki 2008). Groundwater levels are positively related to housing density with increases in groundwater with increasing housing density (Nowicki 2008). In this study, the locations of two of the three salt marshes, Apponaug and Passeonkquis, are located in closer proximity with sewer systems and residential development than Fox Hill. While direct sources of nitrogen into the Bay have been reduced, the local sources such as groundwater and runoff may still be increasing nitrogen levels. In order to determine this, direct measurements of groundwater and runoff inputs into these salt marshes would have to be made.

Another factor that could explain the continued expansion of mussel populations in response to the nitrogen-loading gradient is that the CSO reduces inorganic nitrogen, but organic nitrogen values continue to be as high as or higher than before the installation. It is also possible that all sources of nitrogen into Narragansett Bay are decreasing and instead these mussel populations are experiencing a lag in response to the historically high nitrogen levels. If this is the case, then it is possible that ribbed mussels are not a good indicator species; because if nitrogen levels are decreasing, they are not reflecting the change.

This study serves as an important comparison of the ecology of the ribbed mussel populations along a nitrogen-loading gradient in Narragansett Bay, RI. Using the data from this study, the responses of these ribbed mussel populations to the reduction in nitrogen loading can 
be determined. Future observations of these mussel populations can determine how quickly they respond to these reductions in nitrogen levels, if they respond at all. 


\section{REFERENCES}

Baez, M. (2005). Reproductive cycle of Geukensia demissa (Bivalvia: Mytilidae) on a beach at Nazaret, El Mojan, Zulia State, Venezuela. Ciencias Marinas 31(1A): 111-118.

Bertness, M. D., Ewanchuk, P.J., Silliman, B.R. (2002). Anthropogenic modification of New England salt marsh landscapes. Proceedings of the National Academy of Sciences 99(3): 13951398.

Bertness, M. D. (1984). Ribbed mussels and Spartina alterniflora Production in a New England salt marsh. Ecology 65(6): 1794-1807.

Bertness, M. D. and Grosholz, E. (1985). Population dynamics of the ribbed mussel, Geukensia demissa: the costs and benefits of an aggregated distribution. Oecologia 67(2): 192-204.

Calabretta, C.J., and Oviatt, C.A. (2008). The response of benthic macrofauna to anthropogenic stress in Narragansett Bay, Rhode Island: A review of human stressors and assessment of community conditions." Marine Pollution Bulletin 56:1680-1695.

Chintala, M. M., Wigand, C., and Thursby, G. (2006). Comparison of Geukensia demissa populations in Rhode Island fringe salt marshes with varying nitrogen loads. Marine Ecology Progress Series 329: 101-108.

D’Avanzo, C. and Kremer, J. (1994). Diel oxygen dynamics and anoxic events in an eutrophic estuary of Waquoit Bay, Mass. Estuaries 17: 131-139.

Dauer, D.M. (1993). Biological criteria, environmental health and estuarine macrobenthic community structure. Marine Pollution Bulletin 26(5): 249-257.

Davis, J. L., Nowicki, B., and Wigand, C (2004). Denitrification in fringing salt marshes of Narragansett Bay, Rhode Island, USA. 24 4(870-878).

Evgenidou, A., and Valiela, I. (2002). Response of growth and density of a population of Geukensia demissa to land-derived nitrogen loading, in Waquoit Bay, Massachusetts. Estuarine, Coastal and Shelf Science 55:125-138.

Franz, D.R. (1993). Allometry of shell and body weight in relation to shore level in the intertidal bivalve Geukensia demissa (Bivalvia: Mytilidae). Journal of Experimental Marine Biology and Ecology 174: 193-207.

Franz, D.R. (2001). Recruitment, survivorship and age structure of a New York ribbed mussel populations (Geukensia demissa) in relation to shore level: a nine year study. Estuaries 24(3): 319-327. 
Franz, D.R. (1996). Size and age at first reproduction of the ribbed mussel Geukensia demissa (Dillwyn) in relation to shore level in a New York salt marsh. Journal of Experimental Marine Biology and Ecology 205: 1-13.

Granger, S., Brush, M., Buckley, B., Traber, M., Richardson, M., and Nixon, S.W. (2000). An assessment of eutrophication in Greenwich Bay. Paper No. 1, Restoring water quality in Greenwich Bay: a whitepaper series. Rhode Island Sea Grant, Narragansett, RI.

Hauxwell, J., Cebrian, J., Furlong, C., and Valiela, I. (2001). Macroalgal canopies contribute to eelgrass (Zostera marina) decline in temperate estuarine ecosystems. Ecology 82(4):1007-1022.

Hauxwell, J., Cebrian, J., and Valiela, I. (2003). Eelgrass Zostera marina loss in temperate estuaries: relationship to land-derived nitrogen loads and effect of light limitation imposed by algae. Marine Ecology Progress Series 247:59-73.

Howes, B.L, Weiskel, P.K., Goehringer, D.D., and Teal, J.M. (1996). Interception of freshwater and nitrogen transport from uplands to coastal waters: the role of salt marshes. Estuarine Shores: Evolution, Environments and Human Alterations 287-310. John Wiley and Sons Ltd, New York, NY, USA.

Jordan, T. E. and I. Valiela (1982). A nitrogen budget of the ribbed mussel, Geukensia demissa, and its significance in nitrogen flow in a New England salt marsh. Limnology and Oceanography 27(1): 75-90.

Kuenzler, E.J. (1961). Phosphorus Budget of a Mussel Population. Limnology and Oceanography 6(4):400-415.

Levin, L.A. (2000). Polychaetes as environmental indicators: Response to low oxygen and organic enrichment. Bulletin of Marine Science 61(1):668.

Levine, J. M., Brewer, J.S., and Bertness, M.D. (1998). Nutrients, competition and plant zonation in a New England salt marsh. Journal of Ecology 86(2): 285-292.

McKinney, R.A., Nelson, W.G., Charpentier, M.A., and Wigand, C. (2001). Ribbed mussel nitrogen isotope signatures reflect nitrogen sources in coastal salt marshes. Ecological Applications 11(1):203-214.

Narragansett Bay Commission. (2012). Narragansett Bay Commission 2012 Data Report. Retrieved June 10, 2013 from Narragansett Bay Commission website: (http://snapshot.narrabay.com/app/Services/MossFile.ashx?file=/SiteDirectory/general/devblog/ snapshot/Documents/EMDA\%20Data\%20Reports/2012\%20NBC\%20Annual\%20Data\%20Repo rt.pdf) 
Nixon, S.W., Kelly, J., Furnas, B.N., Oviatt, C.A., and Hale, S.S. (1980). Phosphorus regeneration and the metabolism of coastal marine bottom communities. Marine benthic dynamics 219-242 Columbia, SC: University of South Carolina Press

Nixon, S.W., and Pilson, M.E.Q. (1984). Estuarine total system metabolism and exchange calculated from nutrient ratios: an example from Narragansett Bay. The estaury as a filter 261290. Florida: Academic Press Inc.

Nixon, S.W. (1995). Coastal marine eutrophication: a definition, social causes, and future concerns. Ophelia 41: 199-219.

Nixon, S. W., Granger, S.L., and Nowicki, B.L. (1995). An assessment of the annual mass balance of carbon, nitrogen, and phosphorus in Narragansett Bay. Biogeochemistry 31(1): 15-61.

Nixon, S.W., and Buckley, B. (2002). "A strikingly rich zone"-nutrient enrichment and secondary production in coastal marine ecosystems. Estuaries 25(4b):782-796.

Nowicki, B., Requintina, E., Van Keuren, D., and Portnoy, J. (1999). The role of sediment denitrification in reducing groundwater-derived nitrate inputs to Nauset marsh estuary, Cape Cod, Massachusetts. Estuaries 22: 245-259.

Nowicki, B.L. and Gold, A.J. (2008). Groundwater nitrogen transport and input along the Narragansett Bay coastal margin. In Science of Ecosystem-based Management: Narragansett Bay in the $21^{\text {st }}$ Century, ed. Alan Desbonnet and Barry A Costa-Pierce, 67-100. New York: Springer.

Oviatt, C. A., Buckley, B., and Nixon, S. (1981). Annual phytoplankton metabolism in Narragansett Bay calculated from survey field measurements and microcosm observations Estuaries 4(3): 167-175.

Oviatt, C. A., Keller, A.A., Sampou, P.A., and Beatty, L.L. (1986). Patterns of productivity during eutrophication: a mesocosm experiment. Marine Ecology Progress Series 28: 69-80.

Pruell, R.J., Taplin, B.K., Lake, J.L., and Jayaraman, S. (2006). Nitrogen isotope ratios in estuarine biota collected along a nutrient gradient in Narragansett Bay, Rhode Island, USA. Marine Pollution Bulletin 52: 612-620.

Pryor, D., Saarman, E., Murrary, D., and Prell, W. (2006). Nitrogen loading from wastewater treatment plants to upper Narragansett Bay. Narragansett Bay Estuary Program Report NBEP2007-122. 22 pp. + App. Univ. of RI Coastal Institute, Narragansett, RI, USA.

Ridgeway, I.D., Richardson, C.A., and Austad, S.N. (2011). Maximum shell size, growth rate, and maturation age correlate with longevity in bivalve molluscs. Journal of Gerontology:

Biological Sciences 66A(2): 183-190. 
Rosenberg, R. (2001). Marine benthic faunal successional stages and related sedimentary activity. Scientia Marina 65(2):107-119.

Sfriso, A., Paveni, B., Marcomini, A., and Orio, A.A. (1992). Macroalgae, nutrient cycles, and pollutants in the Lagoon of Venice. Estuaries 15: 517-528.

State of Rhode Island. (2004). Governor's Narragansett Bay and watershed planning commission. Nutrient and bacteria pollution panel report, March 2004. Retrieved June 10, 2013 from URI Coastal Institute website:

(http://www.ci.uri.edu/GovComm/Documents/Phase1Rpt/Docs/Nutrient-Bacteria.pdf).

Smith Jr., K.L. (1985). Deep-sea hydrothermal vent mussels: nutritional state and distribution at the Galapagos Rift. Ecology 66(3):1067-1080.

Tapp, J.F., Shillabeer, N., Ashman, C.M. (1993). Continued observations of the benthic fauna of the industrialized Tees estuary. Journal of Experimental Marine Biology and Ecology 172:67-80.

Toro, J.E.; Thompson, R. J. and Innes, D.J. (2002). Reproductive isolation and reproductive output in two sympatric mussel species (Mytilus edulis, M. trossulus) and their hybrids from Newfoundland. Marine Biology 141: 897-909.

Valente, R. M., Rhoads, D.C., Germano, J.D., and Cabelli, V.J. (1992). Mapping of benthic enrichment patterns in Narragansett Bay, Rhode Island. Estuaries 15(1): 1-17.

Valiela, I., Teal, J.M., and Sass, W.J. (1975). Production and dynamics of salt marsh vegetations and the effects of experimental treatment with sewage slude, biomass, production and species composition. Journal of Applied Ecology 12(3): 973-981.

Valiela, I., Costa, J., Foreman, K., Teal, J.M., Howes, B., and Aubrey, D. (1990). Transport of groundwater-borne nutrients from watersheds and their effect on coastal waters. Biogeochemisty 10:177-197.

Valiela, I. Cole, M., McClelland, J., Hauxwell, J., Cebrian, J., and Joye, S. (2000). Role of salt marshes as a part of coastal landscapes. Concepts and Controversies in Tidal Marsh Ecology 2338. Kluwer, Boston, MA, USA.

Weisberg, S.B., Ranasinghe, J.A., Dauer, D.M., Schaffner, L.C., Diaz, R.J., Frithsen, J.B. (1997). An estuarine benthic index of biotic integrity (B-IBI) for Chesapeake Bay. Estuaries 20(1):149158.

Wigand, C., McKinney, R.A., Charpentier, M.A., Chintala, M.M., and Thursby, G.B. (2003). Relationships of nitrogen loadings, residential development, and physical characteristics with plant structure in New England salt marshes Estuaries 26(6):1494-1504. 
Wigand, C., McKinney, R.A., Chintala, M.M., Charpentier, M.A., and Groffman, P.M. (2004). Denitrification enzyme activity of fringe salt marshes in New England (USA). Journal of Environmental Quality 33: 1144-1151. 
Table 2.1: Salt Marsh Characteristics

\begin{tabular}{llll}
\hline & $\begin{array}{l}\text { Total N-load } \\
\mathrm{kg} \mathrm{N} \mathrm{yr}^{-1}\end{array}$ & $\begin{array}{l}\text { Wastewater input } \\
\%\end{array}$ & $\begin{array}{l}\text { Marsh N-load } \\
\mathrm{kg} \mathrm{N} \mathrm{ha}^{-1} \mathrm{yr}^{-1}\end{array}$ \\
\hline \hline FOX & 103 & 2.3 & 10 \\
PAS & 9,917 & 82.2 & 2,418 \\
APP & 32,472 & 74.5 & 10,253 \\
\hline
\end{tabular}

Table 2.1: Characteristics of the three chosen salt marshes in Narragansett Bay (Wigand et al. 2003) 
Table 2.2: Porewater Nitrogen Concentrations

\begin{tabular}{lllll}
\hline & Ammonia & & \multicolumn{2}{c}{ Nitrate and nitrite } \\
& $\mathrm{Ppb}$ & $\mu \mathrm{M} \mathrm{N}$ & $\mathrm{Ppb}$ & $\mu \mathrm{M} \mathrm{N}$ \\
\hline \hline FOX & 520.00 & 37.14 & 155.00 & 11.07 \\
$\mathrm{PAS}$ & 2025.00 & 144.64 & 178.75 & 12.77 \\
$\mathrm{APP}$ & 641.67 & 45.83 & 1490.00 & 106.43 \\
\hline
\end{tabular}

Table 2.2: Porewater nitrogen concentrations within the three sampled salt marshes in this study. Measurements of ammonia and nitrate/nitrite were averaged for different plot sites and reported in ppb and $\mu \mathrm{M}$ of N. (Data from S.M. MosemanValtierra, URI) 
Table 2.3: Average Density and Biomass of ribbed mussels during Summer 2012

\begin{tabular}{llll}
\hline & $\begin{array}{l}\text { Sample } \\
(\mathrm{n})\end{array}$ & $\begin{array}{l}\text { Density } \\
\left(\mathrm{n} \mathrm{m}^{-2}\right)\end{array}$ & $\begin{array}{l}\text { Biomass } \\
\left(\mathrm{g} \mathrm{AFDW} \mathrm{m}^{-2}\right)\end{array}$ \\
\hline \hline FOX & 13 & $97.8(13.4)$ & $95.2(23.4)^{\mathrm{a}}$ \\
PAS & 11 & $777.2(99.5)$ & $500.5(64.0)^{\mathrm{a}}$ \\
APP & 9 & $3928.9(844.3)$ & $2121.6(139.2)^{\mathrm{b}}$ \\
\hline
\end{tabular}

Table 2.3: Average density and biomass for all months for each site. Standard deviations are in parentheses. Superscripts denote significant differences between sites. Site had a significant effect on biomass ( $\mathrm{F}=$ 38.12, $\mathrm{p}<0.001)$. No significant temporal variations were observed for biomass. 
Table 2.4: Average Condition Index

\begin{tabular}{llll}
\hline & & $\begin{array}{l}\text { Sample } \\
(\mathrm{n})\end{array}$ & $\begin{array}{l}\text { Condition Index } \\
{\left[\left(\mathrm{g} \text { AFDW) }\left(\text { total shell volume } \mathrm{ml}^{-1}\right) \mathrm{x} 1000\right]\right.}\end{array}$ \\
\hline \hline FOX & June & 5 & $41.55(7.33)^{\mathrm{a}}$ \\
& July & 5 & $32.28(7.26)^{\mathrm{b}}$ \\
& August & 3 & $39.88(11.68)^{\mathrm{a}}$ \\
PAS & June & 5 & $50.01(13.81)^{\mathrm{ab}}$ \\
& July & 3 & $46.30(16.20)^{\mathrm{a}}$ \\
& August & 3 & $51.22(11.71)^{\mathrm{b}}$ \\
APP & June & 3 & $74.88(19.88)^{\mathrm{a}}$ \\
& July & 3 & $64.47(21.34)^{\mathrm{b}}$ \\
& August & 3 & $71.81(26.33)^{\mathrm{a}}$ \\
\hline
\end{tabular}

Table 2.4: Average condition index values for each month. Standard deviations are in parentheses. Superscripts denote significant differences between months for each site. Month had a significant effect on CI $(F=10.615, p<0.001)$. Site also had a significant effect on $\mathrm{CI}(\mathrm{F}=195.508, \mathrm{p}<0.001)$. 
Table 2.5: Comparison of density and biomass in ribbed mussels in 1999 (Chintala et al. 2006 and in 2012 (this study)

\begin{tabular}{llll}
\hline & Density & Biomass & Source \\
\hline \hline Fox Hill & $25(5.4)$ & $24(8.6)$ & Chintala et al. (2006) \\
& $97.8(13.4)$ & $95.2(23.4)$ & This study \\
& & & \\
Passeonkquis & $472(109.7)$ & $276(63.3)$ & $\begin{array}{l}\text { Chintala et al. (2006) } \\
\text { This study }\end{array}$ \\
& $777.2(99.5)$ & $500.5(64.0)$ & \\
& & & \\
Apponaug & $1164(255.2)$ & $680(142.3)$ & Chintala et al. (2006) \\
& $3928.9(844.3)$ & $2121.6(139.2)$ & This study \\
\hline
\end{tabular}




\section{FIGURE LEGENDS}

Figure 2.1: Map of Narragansett Bay showing some salt marshes that fringe the area. The three marshes chosen for this study are boxed off (Apponaug (APP), Passeonkquis (PAS), and Fox Hill (FOX)) (Wigand et al. 2003).

Figure 2.2: GSI values for mussels pooled by site and compared by sampling month. The outliers seen are labeled with what site they come from; 1-APP, 2-PAS, and 3-FOX. June shows a high variance with many outliers from Passeonkquis on the upper end of GSI values.

Figure 2.3: GSI values for month of June compared by site. Outliers are individual mussels within each site. 


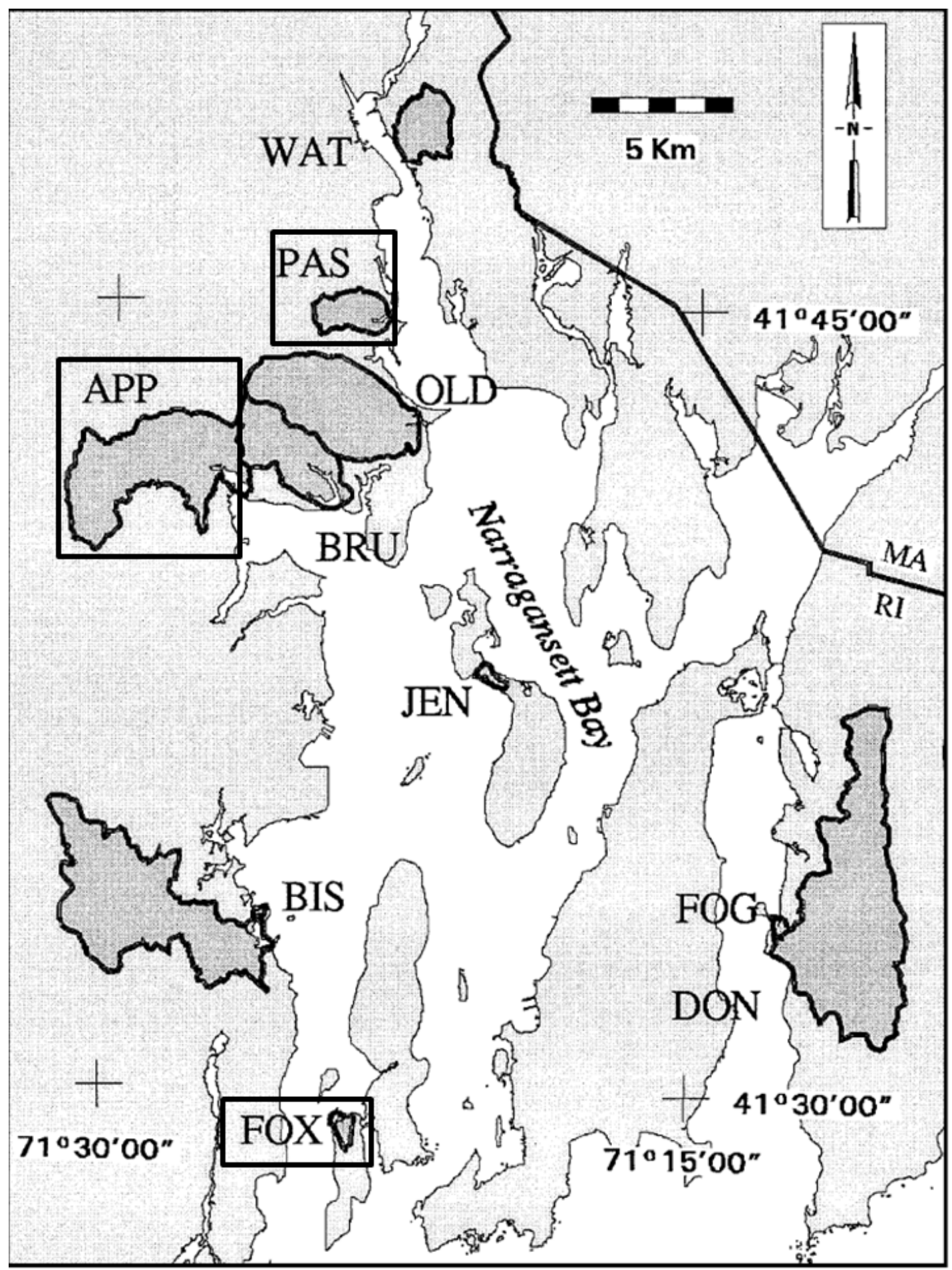

Figure 2.1 


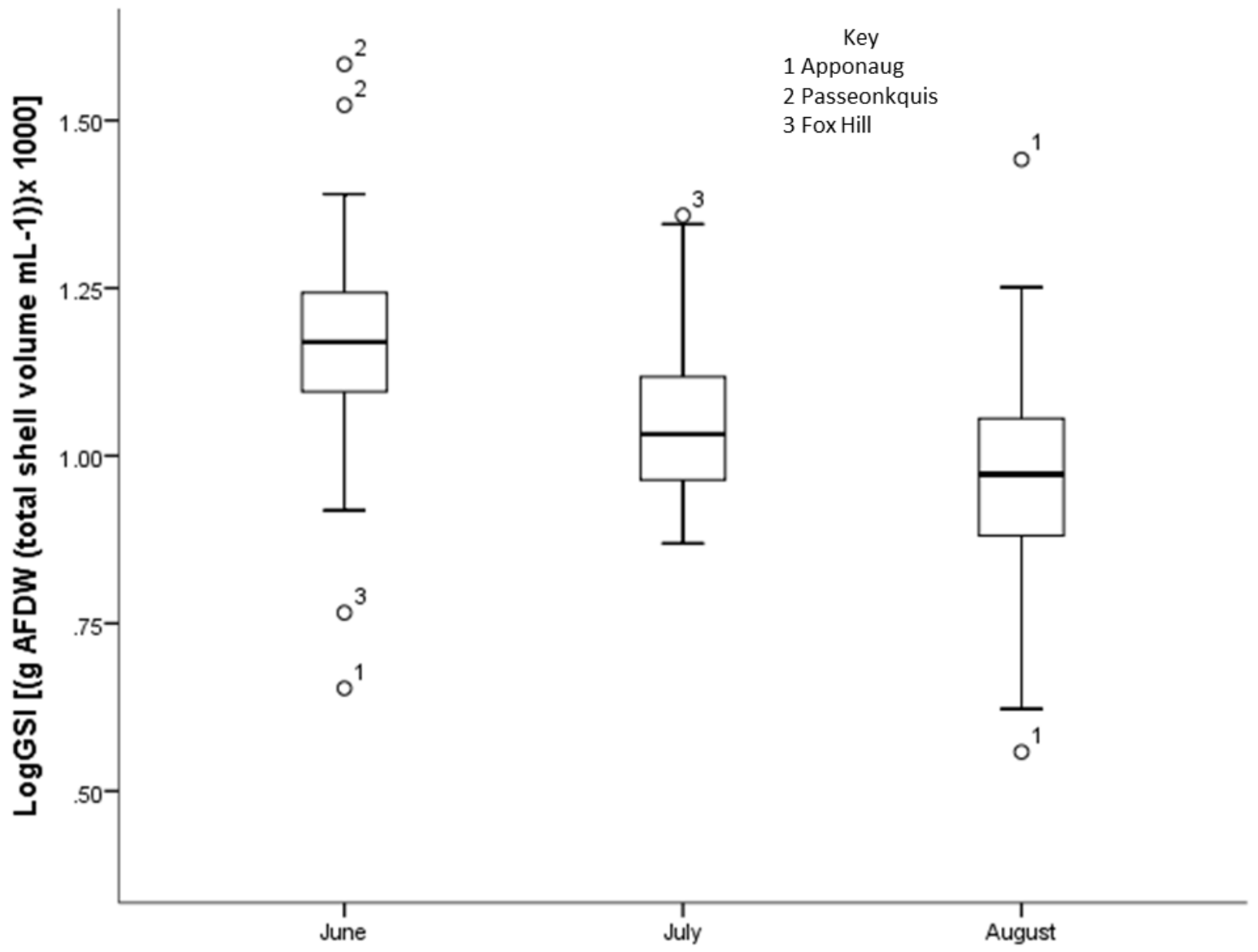

Figure 2.2 


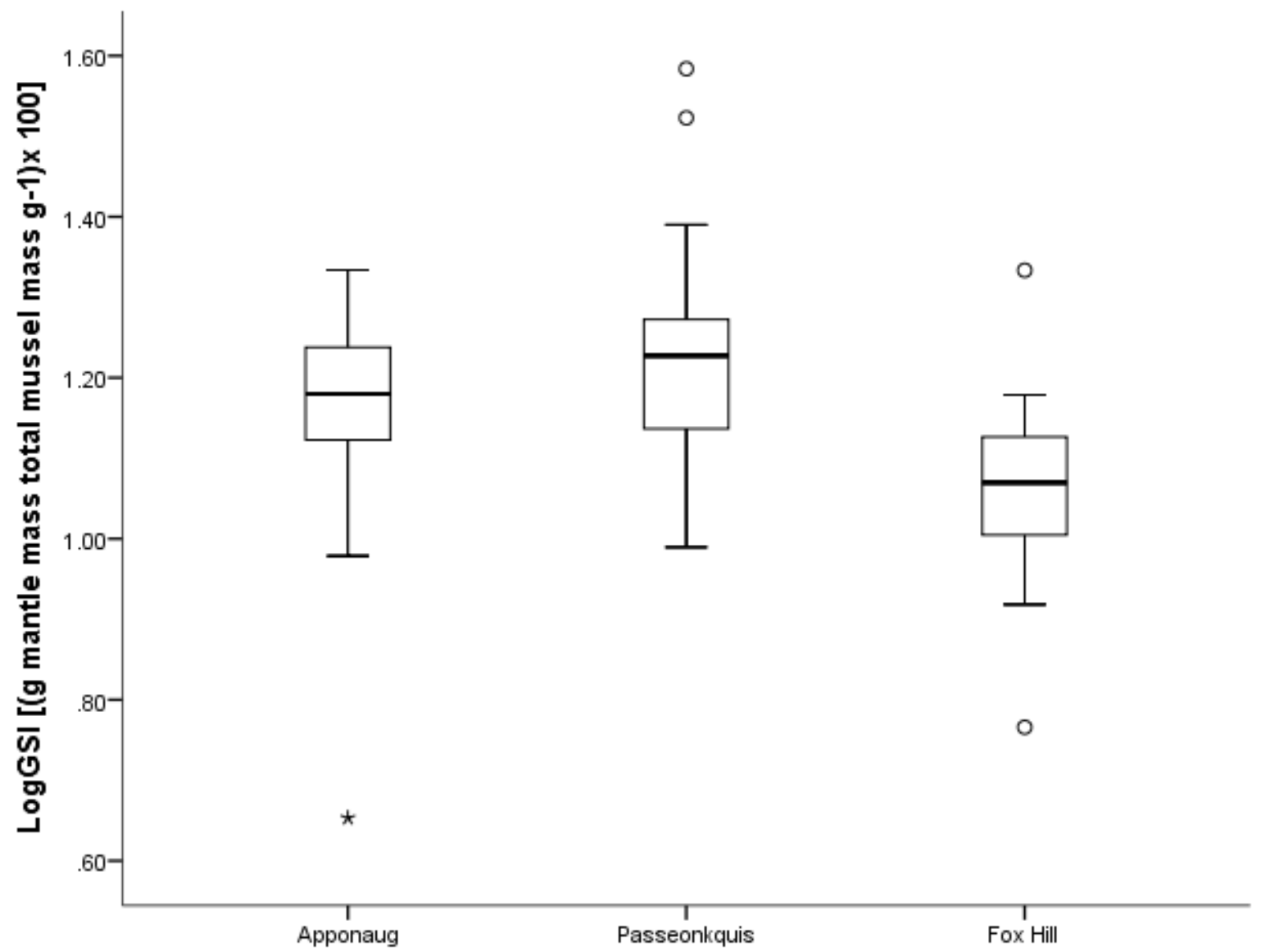

Figure 2.3 


\section{Chapter 3}

\section{Growth of ribbed mussels in Narragansett Bay}

\section{INTRODUCTION}

Excess nutrients or "nitrogen loading" is causing extensive changes to the Narragansett Bay ecosystem, increasing primary production, greenhouse gas emissions, and concentrations of pathogens in the water (e.g. Oviatt et al. 2008, Wigand 2008). Observations of the population dynamics of the ribbed mussel, Geukensia demissa suggest that this species could be a useful indicator of nitrogen loading, based on measurements of mussel biomass, density, and nitrogen stable isotope values from ten Narragansett Bay salt marshes in the late 1990s (Chintala et al. 2006, McKinney et al. 2001, Pruell 2006). A correlation persisted between nitrogen levels and mussel density, biomass, and condition index in 2012 at three of the same marshes representing the range of historic nitrogen levels (Chapter 2). This chapter focuses on analyzing the individual growth rates to obtain a more complete understanding of the population dynamics in these mussel populations. One of the ways in which mussels may respond to an increase in nutrient availability is an increase in individual growth (Evgenidou and Valiela 2002). However, due to the formation of mussel aggregations along the creek banks, growth may be limited by density, which also increases in response to higher nutrient levels (e.g. Stiven and Kuenzler 1979, Bertness and Grosholz 1985, Lin 1989, Stiven and Gardner 1992). Here, two methods are compared, direct and indirect, to determine the growth rates of these individual mussels and to examine the impacts of nitrogen loading on mussel growth.

Bivalve growth is mainly controlled by nutrient availability (Kuenzler 1961, Sprung 1984, Bayne 2004), and the nature of bivalve feeding makes them susceptible to changing levels 
in their food sources. Musculista senhousia, a Pacific saltwater mussel, shows reductions in growth rates with food limitation and Mytilus edulis responds to increased phytoplankton concentrations by increasing growth rates (Allen and Williams 2003, Clausen and Riisgård 1996). G. demissa is a filter-feeder, feeding on the particulate organic matter (POM) in the water column during a tidal cycle. Their diet consists mainly of phytoplankton and Spartina alterniflora detritus, both of which also increase with high nitrogen inputs into the ecosystem (Peterson et al. 1985, 1986; Kreeger et al. 1990; Langdon and Newell 1990). Similar studies on the growth rates of $G$. demissa have shown that growth of small mussels is positively affected by high nitrogen levels (Evgenidou and Valiela 2002). These studies suggest that this increase in growth rates of the mussels is due to the increased food availability of greater phytoplankton concentrations and plant detritus.

Waters in Narragansett Bay have a long residence time (10-40 days), enabling growth of phytoplankton, the dominant primary producer in this estuary (Brush and Nixon 2010, Pilson 1985). Phytoplankton is naturally nitrogen-limited in marine and estuarine systems, and historical nutrient loading into Narragansett Bay has stimulated an increase in phytoplankton concentrations in the Upper Bay (Deacutis 2008). The most recent completion of projects to decrease the nutrient inputs into the Bay from wastewater treatment facilities (CSO tunnel, tertiary treatments) has lowered the amount of organic nitrogen into the Bay (NBC 2012). This decrease in biologically available nitrogen may decrease the phytoplankton concentrations (Deacutis 2008, Brush and Nixon 2010). This decrease in phytoplankton levels may have a negative impact on the $G$. demissa populations inhabiting the fringing salt marshes by limiting their primary food source. 
Bivalves have been used as models for aging and growth due to the nature of their shell growth patterns (Rhoads and Lutz 1980, Ridgway 2011). Shell growth of the ribbed mussel follows an annual cycle with shell deposition occurring from March to November a distruption during the winter. This annual shell deposition results in yearly growth bands, which are visible externally and internally (Figure 1; Brousseau 1984). Internal bands are visible as light lines separated by dark lines when the shell is cut transversely (Brousseau 1984). These light bands are nacreous layers, a common material of mollusk shells, composed of aragonite (a form a calcium carbonate) separated by elastic biopolymers such as chitin (Nudelman et al. 2006). These yearly bands visible in the shell allow for annual individual growth rate determinations. Typically, the lighter bands are thicker and represent slower growth over the winter, and the dark bands are thinner and represent faster growth and the incorporation of phytopigments (King 1995).

The expectation is that mussel growth follows the von Bertalanffy function (Brousseau 1984). This equation produces a logarithmic or decaying exponential curve that approaches the asymptotic length of the species $\left(L_{\infty}\right)$ as a limit (Brousseau 1984). The growth rates therefore are lower for larger mussels and greater for the smaller mussels (Kuenzler 1961b). This reduction in growth rates for larger mussels has been suggested to be due to a change in resource allocation at the greater sizes to reproduction or soft tissue growth (Bayne 2004).

In this study, individual growth rates of ribbed mussel populations in Narragansett Bay from three varying nitrogen loaded salt marshes were determined directly (mark-recapture) and indirectly (shell ring analysis). Annual growth rates were calculated for the past five years for the three mussel populations inhabiting Apponaug, Passeonkquis, and Fox Hill salt marshes. I hypothesized that a density-dependent growth would be seen at Apponaug, the site with the 
highest nitrogen levels within this study, where densities have been shown to be significantly greater than the other two marshes (Chapter 2). I also hypothesized that the growth of individual mussels housed within cages would show greater growth rates at Apponaug due to the release of density-dependence within the cages and higher food availability of phytoplankton.

\section{METHODS}

\section{Study sites, Collections and Size Frequency}

Three salt marshes along Narragansett Bay, RI were selected based on their historical nitrogen levels (Wigand et al. 2003; Table 3.1). These three sites reflect the north to south gradient of decreasing nutrient levels within the Bay with a high, an intermediate and a low nitrogen level site. Apponaug, Warwick is documented to have a total marsh load of $10,253 \mathrm{~kg} \mathrm{~N}$ $\mathrm{ha}^{-1} \mathrm{yr}^{-1}$, Passeonkquis, Warwick has a total marsh load of 2,418 $\mathrm{kg} \mathrm{N} \mathrm{ha}^{-1} \mathrm{yr}^{-1}$ and Fox Hill, Jamestown has a total marsh load of $10 \mathrm{~kg} \mathrm{~N} \mathrm{ha}^{-1} \mathrm{yr}^{-1}$ (Wigand 2003). Although Apponaug is further south than Passeonkquis, Apponaug receives additional nitrogen from point sources in Greenwich Bay, to the west (Wigand et al. 2003). Porewater concentrations of various forms of nitrogen (ammonia and nitrate and nitrite) were measured in this study at each of the salt marshes to determine current levels of nitrogen to these marshes (Table 3.2). The gradients remain for nitrate/nitrite with Fox Hill having the lowest values and Apponaug having the highest values; however, for ammonia levels, Passeonkquis has the highest measured levels with Apponaug and then Fox Hill following with lower and the lowest values, respectively.

Mussel samples were collected June, July, and August of 2012. At each of the marsh sites every month, 3-5 samples were collected using a $25 \mathrm{~cm}$ x $25 \mathrm{~cm}\left(0.0625 \mathrm{~m}^{2}\right)$ sampling square. Collections were made near the marsh edge along tidal creeks at every site. All mussels and 
associated fauna were removed from the area and brought back to the laboratory on ice. All collected mussels were measured for shell length to construct size frequency distributions, and once mussels were dissected to calculate biomass and condition index (see Chapter 2), their shells were cleaned, labeled, dried, and used for growth analysis.

\section{Direct shell growth (mark-recapture)}

In addition to field collections, cages were constructed using $10 \mathrm{~cm}$ x $10 \mathrm{~cm}$ squares of Vexar (plastic) mesh, zip-tied together, to form a cube. Approximately 10-15 mussels were collected for each cage at each site from the low marsh, cleaned, and then tagged with Floy tags adhered with marine cement. The tagged mussels were then measured with calipers for both anterior-posterior and dorsal-ventral shell lengths. Tagged and measured mussels were then placed into respective cages and the cages closed with zip-ties. Three cages were deployed at each salt marsh by tying the cages to a metal stake with polypropylene rope. The stake was positioned within tidal creeks so that cages were within low marsh areas, near uncaged mussels. Cages were deployed in June 2012 and then removed from the sites June 2013. Measurements were taken in June, July, August, and September 2012 and January and June 2013. Annual growth was calculated log transformed to normalize data in order to statistically analyze differences between sites with both ANOVA and Tukey post-hoc test for pooled data and a Kruskal- Wallis rank sum test on separate size classes to determine differences by size. No posthoc tests are available for this nonparametric one-way ANOVA equivalent.

\section{Indirect shell growth (internal shell rings)}


The same mussels collected and analyzed for biomass, condition index, and density (Chapter 2) were used for growth rate analysis. Depending on the number of mussels available from each sample, a maximum of 30 mussels were subsampled from each field collection, for a total of 400 mussels. The right valve of each mussel shell was cut transversely from the umbo to edge using a table wet saw. Cut shells were then coarse and fine sanded to smooth the cut edge to visualize the internal growth bands. Internal bands were visualized using a dissecting microscope and measured from band to umbo using calipers. External growth bands and the earliest growth bands could not be taken due to shell erosion near the umbo of most of the shells. Subsequently, age and the earliest growth rates could not be determined. Instead, growth was analyzed for the past 5 years by measuring the length to the longest 5 growth bands. No mussels smaller than 30 $\mathrm{mm}$ were cut due to cracking of smaller shells that would occur when cut with the wet saw.

\section{Growth rate analysis}

Annual growth rates were calculated for each of the 5 years since sampling in 2012, averaged by $10 \mathrm{~mm}$ size classes, and compared with ANOVA and Tukey post-hoc tests to determine the significant differences among size classes and years. Growth over the period of the previous 5 years was calculated using the von Bertalanffy growth equation,

$$
L_{t}=L_{\infty}\left(1-e^{-K\left(t-t_{0}\right)}\right)
$$

Where $L_{t}=$ length at time t, $L_{\infty}$ is the asymptotic shell length for a given species, $K$ is a constant indicating the rate at which the asymptotic length is approached, and $t_{0}$ is the start of growth (Evgenidou and Valiela 2002, Henry and Nixon 2008). In order to analyze growth rates of these three ribbed mussel populations, this equation was linearized to calculate the $K$ of the three salt marshes, using the equation: $-\operatorname{Ln}\left[1-\left(L_{t} / L_{\infty}\right)\right] v s . t$ (relative age). The slope of the line from 
this plot equals $K$ (Evgenidou and Valiela 2002). This was applied to the data obtained from each of the three salt marshes and the $K$ values were calculated.

\section{RESULTS}

\section{Size Frequency}

Size frequency distributions were examined for mussels collected in June, July, and August 2012 at each of the three marshes, Apponaug, Passeonkquis, and Fox Hill. Assuming age is relative to size, a normal distribution would indicate a stable population with relatively equal rates of recruitment and mortality into the population. A right skew would indicate that there are greater rates of recruitment and higher mortality, and a left skew would indicate that there are lower rates of recruitment and lower mortality.

The size frequency distribution at Apponaug for all three months is skewed to the right with a greater relative abundance (frequency) of smaller mussels $(20-50 \mathrm{~mm}$ ). Larger mussels were less abundant in this salt marsh during the sampled time period. The mussels at Passeonkquis had a more normal distribution of size with a slight skew to the left. There was a higher abundance of mussels within lengths ranging from 50-80 $\mathrm{mm}$. The size frequency at Fox Hill was heavily skewed to the left with zero mussels observed in the smaller size classes $(0-20$ $\mathrm{mm}$ ) and a greater abundance of larger mussels within length ranges of 70-100 mm (Figure 3.3). The shell lengths of the mussel populations at Fox Hill varied temporally, as well as spatially, compared to the other two marshes analyzed. The size distribution observed in the month of 
August at this salt marsh was more skewed to the right than seen in the other two months along with a clear bimodial distribution pattern that might suggest a more recent recruitment event.

\section{Indirect Growth Analysis}

In comparisons of annual growth rates to initial length, size had a significant effect on growth rate $(\mathrm{p}<0.001)$. Therefore, size classes were separated and analyzed independently (Table 3.3). Although site explained a significant portion of the variance in every site class, the variation in growth rates of size classes was not consistent among sites. The growth rate of the 50-60 mm size class was significantly higher at Apponaug than Passeonkquis $(\mathrm{p}=0.001)$. For the 60-70 mm size class, growth rates were higher at Passeonkquis than at Fox Hill $(\mathrm{p}=0.05)$. Both the 70 $80 \mathrm{~mm}$ size class and $80-90 \mathrm{~mm}$ size class had higher growth rates at Apponaug than Passeonkquis (70-80 mm: $\mathrm{p}=0.003 ; 80-90: \mathrm{p}<0.001)$, but growth rates for the $80-90 \mathrm{~mm}$ size class were also greater at Fox Hill than Passeonkquis $(\mathrm{p}=0.015)$. The growth rates for the 90$100 \mathrm{~mm}$ size class were significantly higher at Apponaug than both Fox Hill and Passeonkquis (Fox Hill; $\mathrm{p}=0.001$. Passeonkquis: $\mathrm{p}=0.003$; Table 3.3).

Annual growth for each of the 5 previous years was also compared among size classes from all sites. The growth rate of smallest size classes, 50-60 mm, varied significantly among years. From 2011 to 2012, the average growth rate among sites was significantly higher than in $2009-2010(p=0.002)$ but less than 2007-2008 $(p<0.001)$. From 2010 to 2011 , the growth rate was significantly lower than in either $2009-2010(\mathrm{p}=0.041)$ or $2007-2008(\mathrm{p}<0.001)$. From 2008 to 2009 , the growth rate was also significantly lower than $2007-2008(p=0.007)$. For the $60-70 \mathrm{~mm}$ size class, there were no significant differences in growth rate among the 5 previous years $(\mathrm{p}=0.229)$. The three largest size classes; however, all showed significant differences in growth rates by year. For the $70-80 \mathrm{~mm}$ size class, the growth rates were significantly higher in 
2011-2012 and 2007-2008 than in 2008-2009 (2011-2012: $\mathrm{p}=0.003,2007-2008: \mathrm{p}=0.006)$ but lower in 2010-2011 than 2008-2009 ( $\mathrm{p}=0.001)$. The trend was also detected in both 80-90 and 90-100 mm size classes. In the $80-90 \mathrm{~mm}$ size class, the growth rate in 2011-2012 was significantly greater than $2008-2009(\mathrm{p}=0.003)$ but less in 2008-2009 than $2007-2008(\mathrm{p}=$ 0.033). In the $90-100 \mathrm{~mm}$ size class, the growth rate in 2011-2012 was significantly greater than 2008-2009 $(\mathrm{p}=0.04)$, but less in 2010-2011 and 2008-2009 than in 2007-2008 (2010-2011: $\mathrm{p}=$ 0.006, 2008-2009: $\mathrm{p}=0.002$ ). While the differences in growth rates among the year intervals were highly variable among the years and size classes, and growth rates for 2011-2012 may be artificially higher than expected, based on the distance of the margin of the shell to the last growth band, the growth rates of all size classes in general was fastest in 2007-2008 and slowest in 2010-2011.

By fitting the data to the von Bertalanffy growth equation, differences in the growth coefficient, $K$, were determined (Figure 4). Similar to the patterns observed among the average growth rates at each site, the $K$ values were lowest at Fox Hill (0.106), and higher and similar at Passeonkquis (0.160) and Apponaug (0.161). $K$ is not a measurement of growth rate, but instead approximates the rate of increase to the asymptote $\left(L_{\infty}\right)$ on the growth curve.

\section{Direct growth analysis}

Mussels deployed in cages for one year were pooled together by site, and the average growth rates by size class were compared (Table 3.4). There were no significant differences in growth rates among size classes and sites, with the exception of the $70-80 \mathrm{~mm}$ size class. The growth rate of the mussels in the 70-80 mm size class at Fox Hill was significantly lower than at either Passeonkquis or Apponaug $(\mathrm{p}=0.029)$. After pooling all of the size classes by site, the 
growth rates were found to be significantly lower at Fox Hill than at either Passeonkquis or Apponaug (PA: $\mathrm{p}=0.009$, AP: $\mathrm{p}=0.001)$.

Based on the von Bertalanffy growth curve, the growth coefficient, $K$, was also determined for each site, which showed a decrease in rate towards the asymptote $\left(L_{\infty}\right)$ at Fox Hill (0.045). As with indirect growth measurements, $K$ was higher and similar at Passeonkquis (0.179) and Apponaug (0.162) (Table 3.5).

\section{DISCUSSION}

Growth of the ribbed mussel, Geukensia demissa, has been shown to vary with nutrient availability (Feinstein et al. 1996, Carmichael et al. 2004). Historical nitrogen loading of Narragansett Bay, RI has increased the concentrations of phytoplankton and macroalgae and increased primary production of Spartina alterniflora (Oviatt et al. 2008, Nixon et al. 1995, Bertness and Grosholz 1984). These increases in vegetation within this estuary may impact the food availability of the ribbed mussel populations inhabiting the fringing salt marshes of Narragansett Bay because these producers are main sources of this bivalve's diet. In this study, the growth of individual ribbed mussels within salt marshes along a nitrogen-loading gradient in Narragansett Bay was determined to analyze the responses in growth rates to varying levels of nitrogen. Apponaug marsh had the highest nitrogen load, Passeonkquis had the second highest, and Fox Hill had the lowest nitrogen loads (Wigand et al. 2003).

Fox Hill represents a relatively unperturbed salt marsh, with low levels of nitrogen loading and possible nitrogen limitation, as expected for "natural" marsh conditions. Mussel populations at this marsh appear to have low recruitment, but the mussels that survive appear to 
grow fast to large size relative to mussels at the other two salt marshes as observed by the growth rates and shell lengths. However, compared to the other two salt marshes in this study, growth rates appear to be limited, based on annual growth rates and $K$ values. Mussels at this salt marsh also have been found to have low condition index (Chapter 2), and therefore the populations of mussels may be relatively unhealthy, resulting in slower growth.

Passeonkquis is a moderately impacted salt marsh, with relatively high levels of consistent nitrogen loading. Mussel populations at this marsh have a fairly normal distribution with relatively equal recruitment and mortality. The range in growth rates between small and large mussels is smaller than observed at Fox Hill, suggesting growth rate of small mussels may be less than expected because of the density at this site. As further evidence of the importance of food availability, average growth rates are highest in cages in 2012-2013 at Passeonkquis, where in addition to nitrogen levels in the watershed, there were high densities of macroalgae and swans that may have increased nitrogen levels during that year (pers. obs.). The growth rates determined by indirect methods were also found to be higher at Passeonkquis than at Fox Hill but less than at Apponaug, indicating that there is no limitation on growth at Passeonkquis relative to Fox Hill.

Apponaug represents a highly impacted marsh with high nitrogen levels. Populations of ribbed mussels within this marsh show a skewed distribution pattern with high recruitment and high mortality. Growth rates of these individual mussels were high, but the average shell length was the lowest at this site suggest that size, suggesting mussels may be size-limited at Apponaug. The mussels at this marsh also display high density, biomass, and CI (Chapter 2), indicating that these populations are thriving within this highly impacted salt marsh. Consequently, density may have advantages for this organism, favoring high recruitment and growth rates as a result of 
increased filtration rates (Pales Espinosa et al. 2008, Kempt et al. 1990, Charles and Newell 1997). However, the size of the mussels may be limited due to density (e.g. Bertness and Grosholz 1984), and other factors contribute to a higher rate of mortality than the other sites. In addition to the high nitrogen levels, this exposed marsh borders an active mooring area, where boats or storms are more likely than the other two sites to remove or damage mussels.

The trends in mussel recruitment and growth with nitrogen levels are not necessarily straight-forward. High recruitment and growth rates among all size classes were observed at Apponaug, but the average shell length was the lowest of the three sites. Therefore the added nitrogen may facilitate an increase in density, but density may limit individual growth. Densitydependent growth may also explain the patterns in mussel populations at Passeonkquis, where smaller mussels had a slower growth rate relative to the other two marshes. At Fox Hill, nitrogen levels are low and may reflect the more typical and naturally occurring nitrogen-limited salt marsh. In these conditions, mussels have lower condition index values, but growth rates are higher for small sizes (Fearman et al. 2009).

Results from this work demonstrate that future investigations of the effects of nitrogen loading on the structure and function of salt marshes in the Narragansett Bay ecosystem should not only include density, biomass, condition index of ribbed mussels, but also individual growth rates that may integrate the benefits and costs of increased size and density with higher nitrogen levels. In order to further examine the effects of density on mussel populations, experiments could be designed that would vary mussel density along the creek banks, where they are exposed to a range of environmental conditions, as well as along the well-documented nitrogen-loading gradient in Narragansett Bay. 


\section{REFERENCES}

Allen, B.J., and Williams, S.L. (2003). Native eelgrass Zostera marina controls growth and reproduction of an invasive mussel through food limitation. Marine Ecology Progress Series 254: 57-67.

Bayne, B.L. (2004). Phenotypic flexibility and physiological tradeoffs in the feeding and growth of marine bivalve molluscs. Integrative and Comparative Biology 44(6): 425-432.

Bertness, M. D. and E. Grosholz (1985). Population dynamics of the ribbed mussel, Geukensia demissa: the costs and benefits of an aggregated distribution. Oecologia 67(2): 192-204.

Borrero, F.J., and Hilbish, T.J. (1988). Temporal variation in shell and soft tissue growth of the mussel Geukensia demissa. Marine Ecology Progress Series 42: 9-15.

Brousseau, D. J. (1984). Age and growth rate determinations for Atlantic ribbed mussel, Geukensia demissa Dillwyn (Bivalvia: Mytilidae). Estuaries 7(3): 233-241.

Brush, M.J., and Nixon, S.W. (2010). Modeling the role of macroalgae in a shallow sub-estuary of Narragansett Bay, RI (USA). Ecological Modeling 221: 1065-1079.

Charles, F., and Newell, R.I.E. (1997). Digestive physiology of the ribbed mussel Geukensia demissa (Dillwyn) held at different tidal heights. Journal of Experimental Marine Biology and Ecology 209: 201-213. 
Clausen, I., and Riisgård, H.U. (1996). Growth, filtration and respiration in the mussel Mytilus edulis: no evidence for physiological regulation of the filter-pump to nutritional needs. Marine Ecology Progress Series 141: 37-45.

Deacutis, C.F. (2008). Evidence of ecological impacts from excess nutrients in Upper Narragansett Bay. In Science of Ecosystem-based Management: Narragansett Bay in the $21^{\text {st }}$ Century, ed. Alan Desbonnet and Barry A Costa-Pierce, 349-381. New York: Springer.

Evgenidou, A., and Valiela, I. (2002). Response of growth and density of a population of Geukensia demissa to land-derived nitrogen loading, in Waquoit Bay, Massachusetts. Estuarine, Coastal and Shelf Science 55:125-138.

Feinstein, N., Yelenik, S., McClelland, J., and Valiela, I. (1996). Growth rates of ribbed mussels in six estuaries subject to different nutrient loads. Biological Bulletin 191: 327-328.

Franz, D.R. (1993). Allometry of shell and body weight in relation to shore level in the intertidal bivalve Geukensia demissa (Bivalvia: Mytilidae). Journal of Experimental Marine Biology and Ecology 174: 193-207.

Franz, D.R. (2001). Recruitment, survivorship and age structure of a New York ribbed mussel populations (Geukensia demissa) in relation to shore level: a nine year study. Estuaries 24(3): 319-327.

Henry, K.M., and Nixon, S.W. (2008). A half century assessment of hard clam, Mercenaria mercenaria, growth in Narragansett Bay, Rhode Island. Estuaries and Coasts 31: 755-766.

Huang, S.-C., Kreeger, D.A., and Newell, R.I.E. (2003). Seston available as a food resource for the ribbed mussel (Geukensia demissa) in a North American, mid-Atlantic saltmarsh. Estuarine, Coastal and Shelf Science 56: 561-571.

Jordan, T. E. and I. Valiela (1982). A nitrogen budget of the ribbed mussel, Geukensia demissa, and its significance in nitrogen flow in a New England salt marsh. Limnology and Oceanography 27(1): 75-90.

Kemp, P.F., Newell, S.Y., and Krambeck, C. (1990). Effects of filter-feeding by the ribbed mussel Geukensia demissa on the water-column microbiota of a Spartina alterniflora saltmarsh. Marine Ecology Progress Series 59: 119-131.

King, M. (1995). Fisheries Biology, Assessment and Management. Blackwell Science, Inc., Cambridge, MA. 388 p.

Kreeger, D.A., Newell, R.I.E., and Langdon, C.J. (1990). Effect of tidal exposure on utilization of dietary lignocellulose by the ribbed mussel Geukensia demissa (Dillwyn) (Mollusca:

Bivalvia). Journal of Experimental Marine Biology and Ecology 144: 85-100. 
Kuenzler, E. J. (1961a). Structure and energy flow of a mussel population in a Georgia salt marsh. Limnology and Oceanography 6(2): 191-204.

Kuenzler, E. J. (1961b). Phosphorus budget of a mussel population. Limnology and Oceanography 6(4): 400-415.

Langdon, C.J. and Newell, R.I.E. (1990). Utilization of detritus and bacteria as food sources by two bivalve suspension-feeders, the oyster Crassostra virginica and the mussel Geukensia demissa. Marine Ecology Progress Series 58: 299-310.

Lin, J. (1989). Importance of location in the salt marsh and clump size on growth of ribbed mussels. Journal of Experimental Marine Biology and Ecology 128: 75-86.

Nudelman, F., Gotliv, B.A., Addadi, L., and Weiner, S. (2006). Mollusk shell formation: Mapping the distribution of organic matrix components underlying a single aragonitic tablet in nacre. Journal of Structural Biology 153(2): 176-187.

Pales Espinosa, E., Allam, B., and Ford, S.E. (2008). Particle selection in the ribbed mussel Geukensia demissa and the Eastern oyster Crassostrea virginica: Effect of microalgae growth stage. Estuaries, Coastal and Shelf Science 79: 1-6.

Peterson, B.J., Howarth, R.W., and Garritt, R.H. (1985). Multiple stable isotopes used to trace the flow matter in estuarine food webs. Science 227: 1361-1363.

Peterson, B.J., Howarth, R.W., and Garritt, R.H. (1986). Sulfur and carbon isotopes as tracers of salt-marsh organic matter flow. Ecology 67: 865-874.

Pilson, M.E.Q. (1985). Annual cycles of nutrients and chlorophyll in Narragansett Bay, Rhode Island. Journal of Marine Research 43: 849-873.

Rhoads, D.C., and Lutz, R.A. (1980). Skeletal growth of aquatic organisms. Plenum Publishing Corporation, New York. 750 p.

Ridgeway, I.D., Richardson, C.A., and Austad, S.N. (2011). Maximum shell size, growth rate, and maturation age correlate with longevity in bivalve molluscs. Journal of Gerontology:

Biological Sciences 66A(2): 183-190.

Sprung, M. (1984). Physiological energetics of mussel larvae (Mytilus edulis). I. Shell growth and biomass. Marine Ecology Progress Series 17: 283-293.

Stiven, A.E., and Gardner, S.A. (1992). Population processes in the ribbed mussel Geukensia demissa (Dillwyn) in a North Carolina salt marsh tidal gradient: spatial pattern, predation, growth and mortality. Journal of Experimental Marine Biology and Ecology 160: 81-102. 
Stiven, A.E., and Kuenzler, E.J. (1979). The response of two salt marsh molluscs, Littorina irrorata and Geukensia demissa, to field manipulations of density and Spartina litter. Ecological Monographs 49(2): 151-171.

Table 3.1: Salt Marsh Characteristics

\begin{tabular}{llll}
\hline & $\begin{array}{c}\text { Total N-load } \\
\mathrm{kg} \mathrm{N} \mathrm{yr}^{-1}\end{array}$ & $\begin{array}{l}\text { Wastewater input } \\
\%\end{array}$ & $\begin{array}{l}\text { Marsh N-load } \\
\mathrm{kg} \mathrm{N} \mathrm{ha}^{-1} \mathrm{yr}^{-1}\end{array}$ \\
\hline \hline FOX & 103 & 2.3 & 10 \\
PAS & 9,917 & 82.2 & 2,418 \\
APP & 32,472 & 74.5 & 10,253 \\
\hline \multicolumn{2}{l}{ Table 1: Characteristics of the three chosen salt marshes in } \\
Narragansett Bay (Wigand et al. 2003)
\end{tabular}


Table 3.2: Porewater Nitrogen Concentrations

\begin{tabular}{lllll}
\hline & \multicolumn{2}{c}{ Ammonia } & & \multicolumn{2}{c}{ Nitrate and nitrite } \\
& $\mathrm{ppb}$ & $\mu \mathrm{M} \mathrm{N}$ & $\mathrm{ppb}$ & $\mu \mathrm{M} \mathrm{N}$ \\
\hline \hline FOX & 520.00 & 37.14 & 155.00 & 11.07 \\
PAS & 2025.00 & 144.64 & 178.75 & 12.77 \\
$\mathrm{APP}$ & 641.67 & 45.83 & 1490.00 & 106.43 \\
\hline
\end{tabular}

Table 2: Porewater nitrogen concentrations within the three sampled salt marshes in this study. Measurements of ammonia and nitrate/nitrite were averaged for different plot sites and reported in $\mathrm{ppb}$ and $\mu \mathrm{M}$ of $\mathrm{N}$ (Data from S.M. MosemanValtierra, URI). 
Table 3.3: Comparison of annual change in shell length among size classes of mussels at each site from 2007-2012.

\begin{tabular}{lcccccr}
\hline A. 50-60 mm & n & $\mathbf{2 0 0 7 - 2 0 0 8}$ & $\mathbf{2 0 0 8 - 2 0 0 9}$ & $\mathbf{2 0 0 9 - 2 0 1 0}$ & $\mathbf{2 0 1 0 - 2 0 1 1}$ & $\mathbf{2 0 1 1 - 2 0 1 2}$ \\
\hline \hline Fox Hill & 4 & $11.2(2.77)$ & $8.53(2.21)$ & $7.95(1.52)$ & $7.08(1.54)$ & $4.2(1.65)$ \\
Passeonkquis & 30 & $7.45(3.28)$ & $8.26(2.16)$ & $9.13(3.51)$ & $6.30(1.79)$ & $7.42(0.51)$ \\
Apponaug & 14 & $12.57(2.9)$ & $4.33(2.85)$ & $4.91(2.49)$ & $4.74(1.98)$ & $2.71(1.27)$ \\
\hline & & & & & & \\
\hline B. 60-70 mm & n & $\mathbf{2 0 0 7 - 2 0 0 8}$ & $\mathbf{2 0 0 8 - 2 0 0 9}$ & $\mathbf{2 0 0 9 - 2 0 1 0}$ & $\mathbf{2 0 1 0 - 2 0 1 1}$ & $\mathbf{2 0 1 1 - 2 0 1 2}$ \\
\hline \hline Fox Hill & 11 & $6.58(3.09)$ & $4.19(1.13)$ & $4.11(2.66)$ & $4.14(2.49)$ & $4.23(2.59)$ \\
Passeonkquis & 56 & $7.04(1.12)$ & $6.45(1.65)$ & $5.92(0.94)$ & $4.67(0.66)$ & $6.93(0.39)$ \\
Apponaug & 32 & $6.10(0.14)$ & $5.83(1.53)$ & $7.33(1.96)$ & $4.96(0.96)$ & $5.28(1.55)$ \\
\hline & & & & & & \\
\hline C. 70-80 mm & $\mathbf{n}$ & $\mathbf{2 0 0 7 - 2 0 0 8}$ & $\mathbf{2 0 0 8 - 2 0 0 9}$ & $\mathbf{2 0 0 9}-2010$ & $\mathbf{2 0 1 0 - 2 0 1 1}$ & $\mathbf{2 0 1 1 - 2 0 1 2}$ \\
\hline \hline Fox Hill & 19 & $6.41(1.10)$ & $5.48(1.25)$ & $4.60(1.41)$ & $3.55(1.13)$ & $6.25(1.41)$ \\
Passeonkquis & 69 & $4.55(1.27)$ & $4.41(1.47)$ & $3.73(0.46)$ & $3.08(0.37)$ & $5.95(1.45)$ \\
Apponaug & 74 & $6.93(1.45)$ & $6.81(1.03)$ & $6.16(0.47)$ & $4.10(0.99)$ & $5.19(0.96)$ \\
\hline & & & & & & \\
\hline D. 80-90 mm & $\mathbf{n}$ & $\mathbf{2 0 0 7 - 2 0 0 8}$ & $\mathbf{2 0 0 8 - 2 0 0 9}$ & $\mathbf{2 0 0 9 - 2 0 1 0}$ & $\mathbf{2 0 1 0 - 2 0 1 1}$ & $\mathbf{2 0 1 1 - 2 0 1 2}$ \\
\hline \hline Fox Hill & 14 & $5.47(0.30)$ & $4.76(0.53)$ & $5.20(1.75)$ & $3.91(0.64)$ & $5.13(1.83)$ \\
Passeonkquis & 32 & $4.16(1.59)$ & $3.08(0.86)$ & $2.99(0.53)$ & $2.65(0.87)$ & $5.28(1.21)$ \\
Apponaug & 44 & $7.59(1.65)$ & $5.99(1.04)$ & $5.11(1.01)$ & $4.07(1.04)$ & $5.24(1.06)$ \\
\hline & & & & & & \\
\hline E. 90-100 mm & $\mathbf{n}$ & $\mathbf{2 0 0 7 - 2 0 0 8}$ & $\mathbf{2 0 0 8 - 2 0 0 9}$ & $\mathbf{2 0 0 9 - 2 0 1 0}$ & $\mathbf{2 0 1 0 - 2 0 1 1}$ & $\mathbf{2 0 1 1 - 2 0 1 2}$ \\
\hline \hline Fox Hill & 6 & $2.68(0.60)$ & $2.15(0.64)$ & $3.29(1.07)$ & $1.50(0.49)$ & $4.15(1.20)$ \\
Passeonkquis & 5 & $3.77(0.62)$ & $2.35(0.49)$ & $2.29(0.13)$ & $3.24(0.93)$ & $4.50(0.71)$ \\
& & & & & & \\
\hline & & & & & & \\
\hline
\end{tabular}




\begin{tabular}{lllllll} 
Apponaug & 7 & $7.48(1.95)$ & $3.95(0.57)$ & $5.13(0.35)$ & $2.73(0.67)$ & $8.70(3.96)$ \\
\hline
\end{tabular}

Table 3.3: Average change in growth between each year from 2007-2008 are shown for the 5 size classes analyzed; $50-60 \mathrm{~mm}, 60-70 \mathrm{~mm}, 70-80 \mathrm{~mm}, 80-90 \mathrm{~mm}$, and $90-100 \mathrm{~mm}$ shown in A, B, C, D, and E. Standard deviations are given in parentheses.

Table 3.4: Average annual change in shell length of direct growth analysis for 2012-2013

\begin{tabular}{lcccr}
\hline Size Class & n & FH & PA & AP \\
\hline \hline $30-40 \mathrm{~mm}$ & 2 & N/A & 9.8 & 11.1 \\
$40-50 \mathrm{~mm}$ & 2 & N/A & N/A & $7.9(1.13)$ \\
$50-60 \mathrm{~mm}$ & 8 & $1.23(0.67)$ & $2.63(2.46)$ & $2.35(2.33)$ \\
$60-70 \mathrm{~mm}$ & 14 & $1.08(0.70)$ & $2.3(1.13)$ & $2.87(0.75)$ \\
$70-80 \mathrm{~mm}$ & 13 & $0.63(0.35)$ & $1.77(0.90)$ & $1.73(0.48)$ \\
$80-90 \mathrm{~mm}$ & 16 & $0.33(0.50)$ & N/A & $0.74(1.03)$ \\
$90-100 \mathrm{~mm}$ & 3 & N/A & N/A & $0.97(0.40)$ \\
\hline
\end{tabular}

Table 3.4: All sites and size classes are represented in the table. N/A designates that mussels were not collected in that size range. Standard deviations are in parentheses. 
Table 3.5: $K$ and $L_{\infty}$ values of direct growth analysis

\begin{tabular}{llc}
\hline & K & $\boldsymbol{L}_{\infty}$ \\
\hline \hline FOX & 0.044678 & 88.48000356 \\
PAS & 0.178561 & 80.75745491 \\
APP & 0.162286 & 89.85739789 \\
\hline
\end{tabular}




\section{FIGURE LEGENDS}

Figure 3.1: Image of external growth bands. Pericostracum is intact and indents in the shell can be seen. The bands are very clear and could be seen by the naked eyes. Photo credit: Janis Hall

Figure 3.2: Image of shell erosion. Cut mussel shell within the lab showing dissolved pericostracum and a large dent within the shell. This makes any visualization of bands (either internal or external) impossible. Photo credit: Janis Hall

Figure 3.3: Size frequency distributions of Geukensia demissa for months June, July and August from all three salt marshes (A) Apponaug, (B) Passeonkquis, and (C) Fox Hill. Mussel length was put into size classes of $10 \mathrm{~mm}$ increments and then frequency of mussels within those size classes was determined.

Figure 3.4: The factor $-\operatorname{Ln}\left(1-\left(L_{t} / L_{\infty}\right)\right)$ calculated for mussels from the three salt marshes, Apponaug (AP), Passeonkquis (PA), and Fox Hill (FH) and plotted vs. relative age (years) for each site. The slope of each curve corresponds to the $K$ on von Bertalanffy equation. Points correspond to averaged values across months. Regression analyses:

$\mathrm{y}=0.106 \mathrm{x}+0.611, \mathrm{R}^{2}=0.988$ (Fox Hill), $\mathrm{y}=0.160 \mathrm{x}+0.512, \mathrm{R}^{2}=0.9714$ (Passeonkquis), $\mathrm{y}=$ $0.161 x+0.470, R^{2}=0.997$ (Apponaug). 


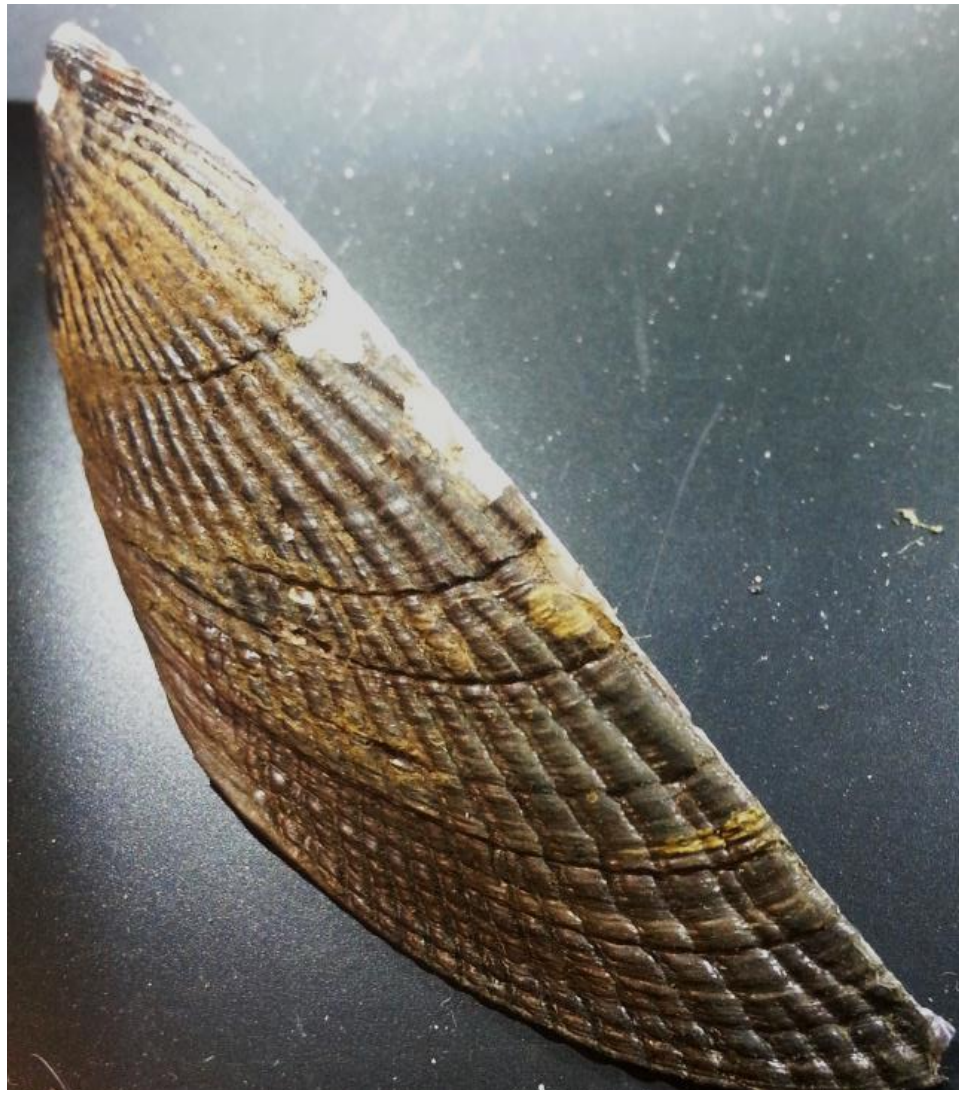


Figure 3.1

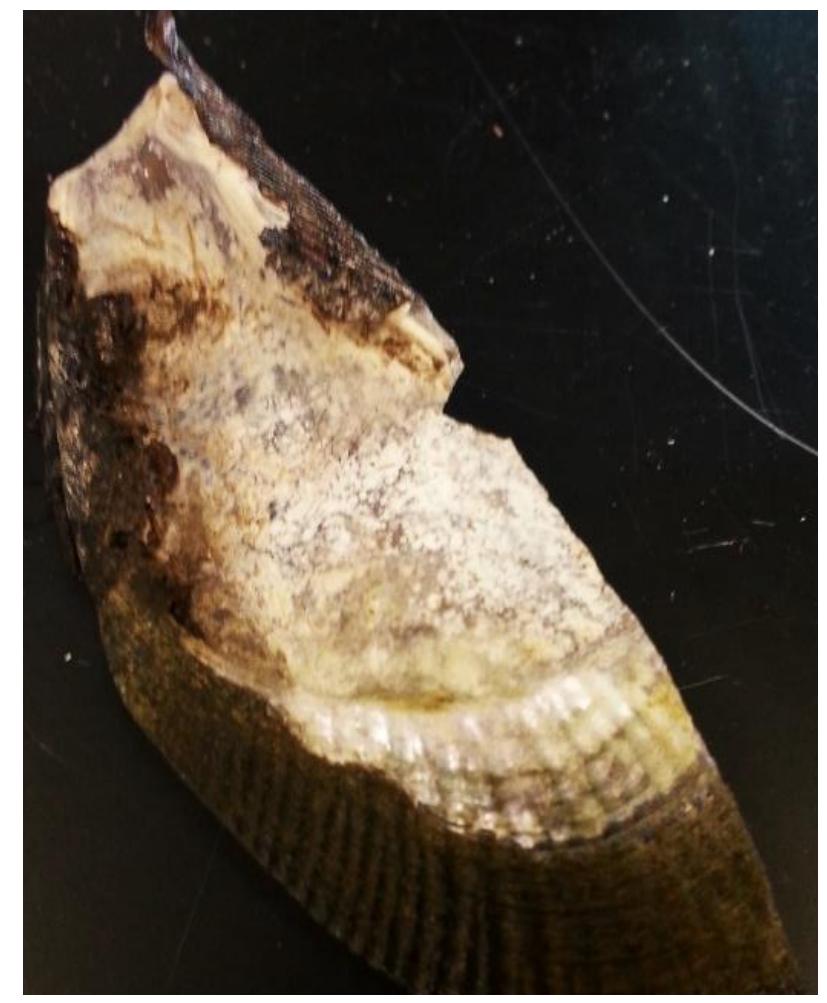

Figure 3.2 

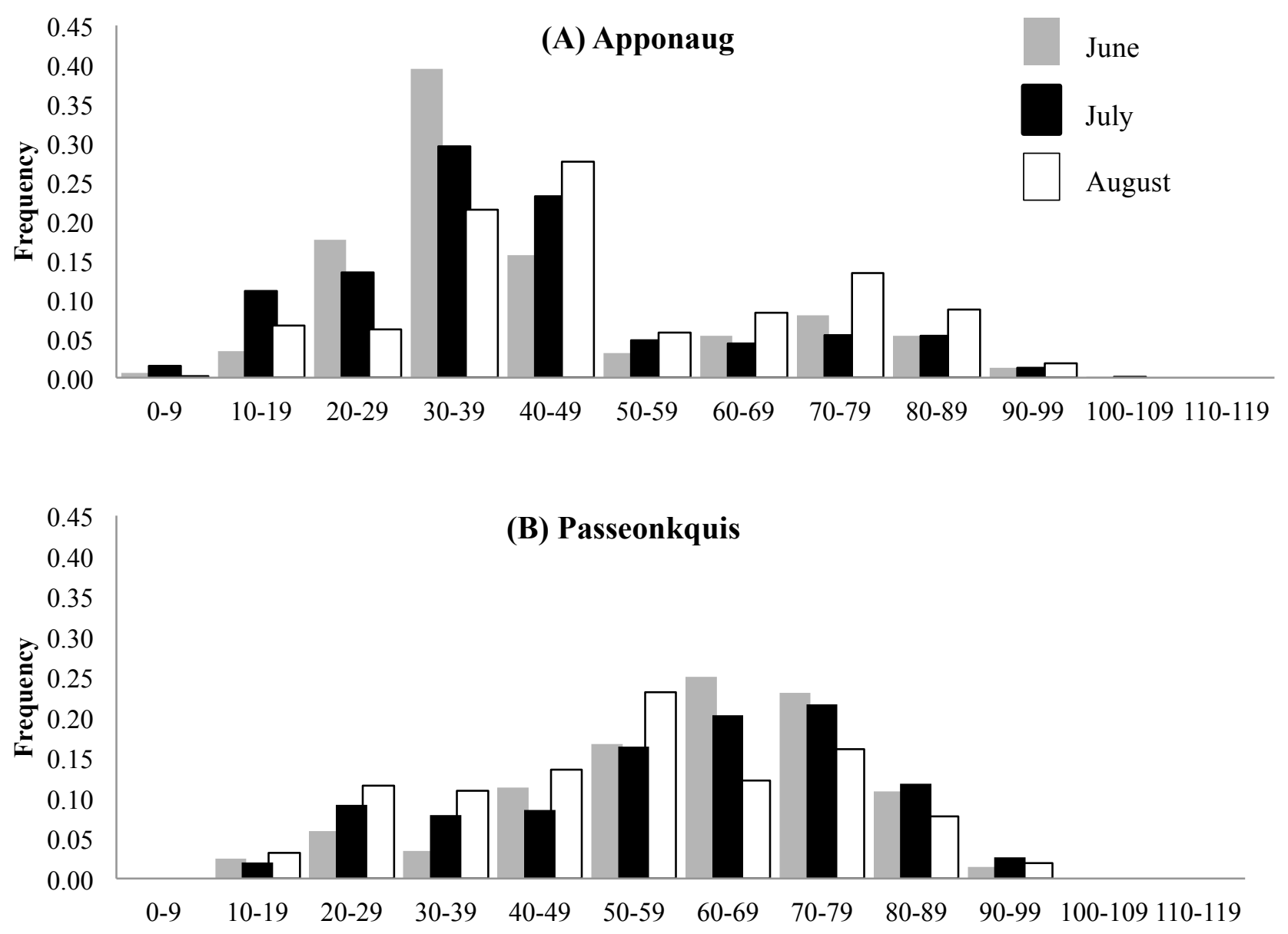

(C) Fox Hill

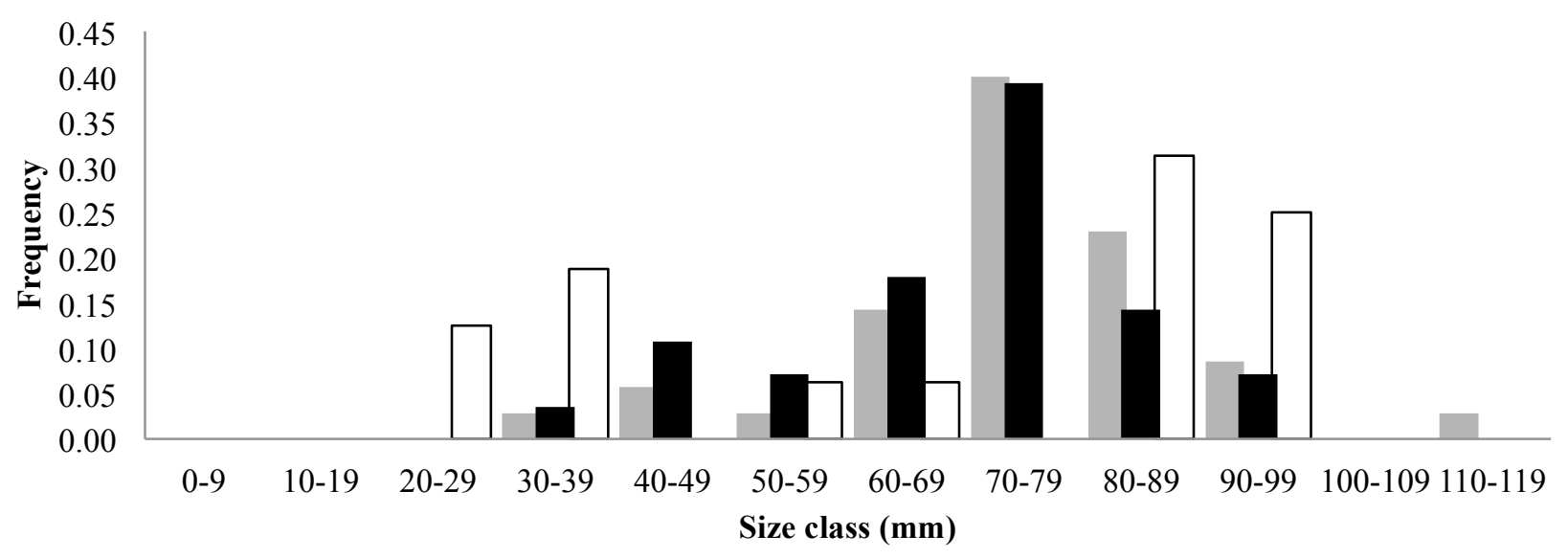

Figure 3.3 


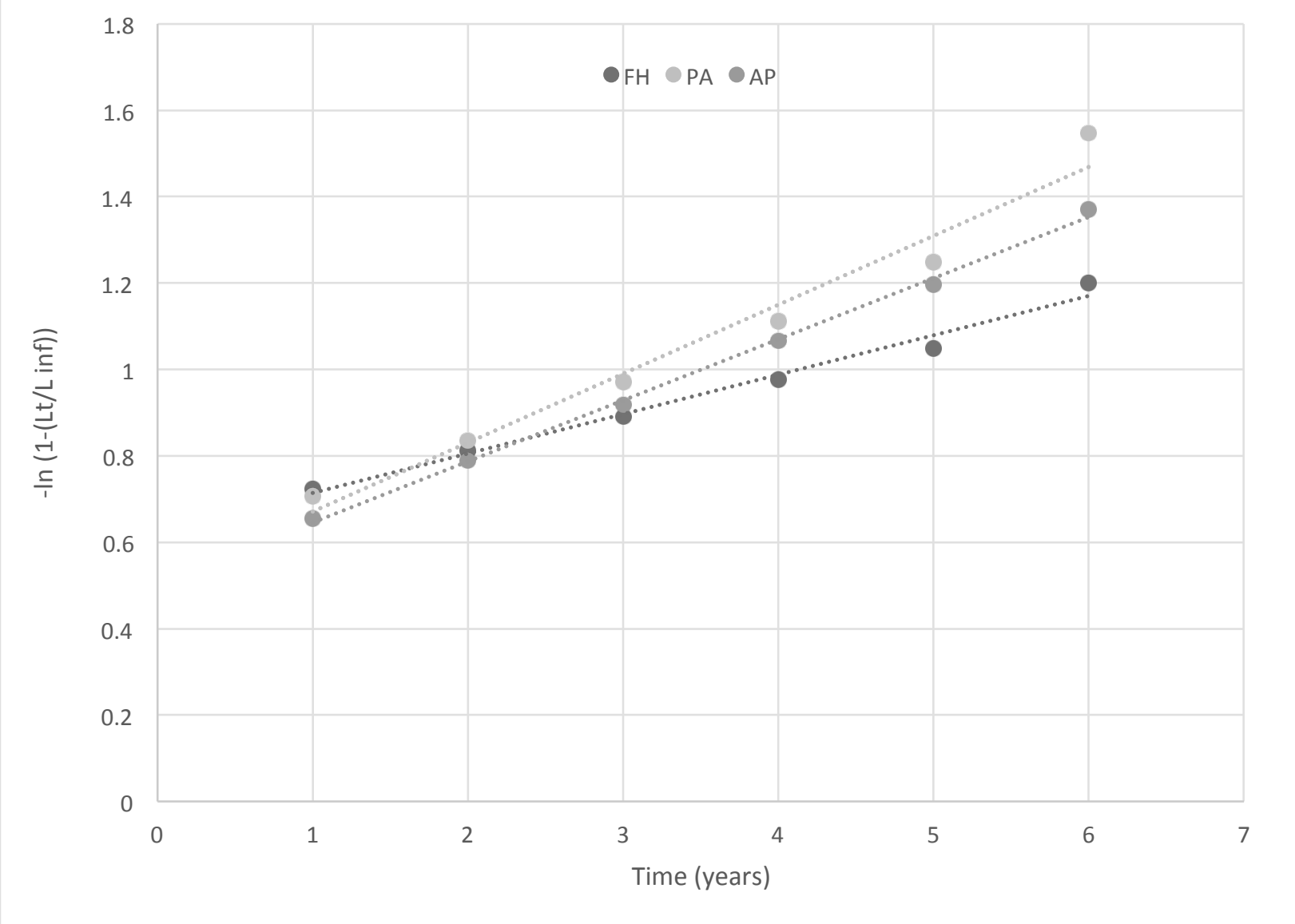

Figure 3.4 


\section{Chapter 4}

\section{Conclusions}

Historically, human development has increased along shorelines, and increasing human population density has led to greater nutrient inputs into coastal ecosystems. This nutrient enrichment of coastal estuaries has been found to increase primary production, change plant species composition and density, decrease oxygen concentrations in the water, and alter benthic communities. In 1998-1999, the ribbed mussel Geukensia demissa population in Narragansett Bay, the largest estuary in New England, was found to increase in biomass, density, and condition index in salt marshes with high levels of nitrogen loading (Chintala et al. 2006). In 2008, changes to wastewater treatment facilities resulted in lowered concentrations of nutrients into Narragansett Bay. The purpose of my thesis was to investigate the variation in ribbed mussel populations along the historical nitrogen-loading gradient documented in Narragansett Bay since 2008, and to construct a baseline for ribbed mussel responses to decreasing nitrogen levels following the installation of additional wastewater treatment infrastructure.

The results of my work demonstrate that $G$. demissa populations within impacted salt marshes in Narragansett Bay, RI is that populations are continuing to expand with increases in nitrogen loads. High levels of nutrients in a salt marsh stimulate increases in density, biomass, and condition index of the ribbed mussel populations. However, increased density resulting from the higher nitrogen levels may also have negative consequences, including reduced size and slower growth rates in smaller mussels. While fecundity appears to be unaffected by changes in nutrient availability to these organisms, recruitment and individual growth rates increase with 
nitrogen loading, and in the salt marsh with the lowest nitrogen levels, recruitment and growth rates were much lower.

Overall, ribbed mussels in Narragansett Bay may be experiencing "too much of a good thing”. In 2012, the mussel populations seem to be thriving in marshes with elevated nitrogen loads and potentially waning in marshes with the lowest nitrogen levels. However, density may be limiting individual growth suggesting that these populations are starting to experience declines in size and growth rate. With an increase in the density of mussels, increased competition for space and resources can lead to increased mortality within these populations and the eventual declines in the distribution of this species, having larger scale consequences on the ecology of salt marshes in Narragansett Bay.

In comparison to ribbed mussel populations from the same salt marshes in 1999 (Chintala et al. 2006), it appears that $G$. demissa populations are continuing to expand with increases in density, biomass, and condition index. These patterns suggest that while attempts have been made to decrease the levels of nitrogen inputs into the Bay, that these populations are still exhibiting effects of nutrient enrichment. This may be due to delayed effects in the response of mussel populations to lowered nitrogen, or that these values represent a decrease from higher values that were not documented before 1999.

The variation in the mussel populations at the three sampled marshes in 2012 are presumably due to the greater food availability that occurs from the increased nutrient loads. With more food, the mussels have more energy to allocate to growth and reproduction. While there were no statistical differences in fecundity among mussel populations at the three sites, 
recruitment may increase at marshes with elevated nitrogen levels (Bertness 2007). This would explain the increase in density at these marshes despite the lack of correlation to fecundity.

Nitrogen loading is causing large-scale change at Narragansett Bay and other estuaries, as well as in marine, freshwater, and terrestrial habitats. In order to understand the consequences, it is important to compare populations along a nitrogen-loading gradient and to historical datasets. While efforts are being made to reduce nitrogen loading in Narragansett Bay, it is unclear how one of the indicator species, the ribbed mussel, will respond to decreased nitrogen levels in salt marshes. My thesis serves as an important time point to compare datasets in the late 1990s to the present and to form a new baseline to which to compare datasets after the completion of the sewage abatement program. 